\title{
High Content of Boron in Curative Water: From the Spa to Industrial Recovery of Borates? (Poland as a Case Study)
}

\author{
Katarzyna Chruszcz-Lipska *, Bogumiła Winid, Gabriela Anna Madalska, Jan Macuda and Łukasz Łukańko
}

check for updates

Citation: Chruszcz-Lipska, K.; Winid, B.; Madalska, G.A.; Macuda, J.; Łukańko Ł. High Content of Boron in Curative Water: From the Spa to Industrial Recovery of Borates? (Poland as a Case Study). Minerals 2021, 11, 8 . https://dx.doi.org/10.3390/min 11010008

Received: 6 November 2020 Accepted: 19 December 2020 Published: 24 December 2020

Publisher's Note: MDPI stays neutral with regard to jurisdictional claims in published maps and institutional affiliations.

Copyright: () 2020 by the authors. Licensee MDPI, Basel, Switzerland. This article is an open access article distributed under the terms and conditions of the Creative Commons Attribution (CC BY) license (https: / / creativecommons.org/ licenses/by/4.0/).
Faculty of Drilling, Oil and Gas, AGH University of Science and Technology, al. Mickiewicza 30, 30-059 Kraków, Poland; winid@agh.edu.pl (B.W.); gabriela.madalska@gmail.com (G.A.M.); macuda@agh.edu.pl (J.M.); lukanko@agh.edu.pl (Ł.Ł.)

* Correspondence: lipska@agh.edu.pl; Tel.: +48-12-617-2241

\begin{abstract}
Boron minerals are a sought-after raw material. The European Union's total dependence on imported borates means that this has been a critical material since 2014. Due to the increased use of borates in modern economies, data on the predicted boron demand in the coming years indicate that it may become a critical element on a global scale. Formerly, the high boron content in groundwater was the basis for qualifying it as medicinal water (boric water). Nevertheless, the current information on the potential toxicity of boron and the narrow margin between deficiency and toxicity of boron in the human body has caused a tightening of the limits of this element in water intended for human consumption. For this reason, metaboric acid has lost its position as a specific component of curative waters. However, despite the fact that boron is not currently a specific component of curative waters, it is found in measureable concentrations in Polish medicinal water considered therapeutic based on other valuable specific components. High boron content in curative water may be the cause of the problems in some spas when obtaining certificates confirming the therapeutic properties of waters. Literature data indicate that waters with high boron content (above $25 \mathrm{mg} / \mathrm{L}$ ) should not be freely available for drinking in pump rooms and other places in health resorts. To identify the situation with Polish health resorts, the content of boron in 248 curative water samples was analyzed. In 154 of these samples, the boron concentration was relatively low and did not exceed $5 \mathrm{mg} / \mathrm{L}$. However, in the remaining 94 samples, the boron content exceeded $5 \mathrm{mg} / \mathrm{L}$, and 38 samples had boron content exceeding $30 \mathrm{mg} / \mathrm{L}$. Ten of the 248 samples of curative water had a boron concentration above $100 \mathrm{mg} / \mathrm{L}$, which may be a potential source of boron for industrial recovery. The highest concentration of boron was noticed in a water sample from the Wysowa health resort and was $187.6 \mathrm{mg} / \mathrm{L}$. Unfortunately, most of water intakes with a high concentration of boron (above $100 \mathrm{mg} / \mathrm{L}$ ) are low-yielding wells. Based on the data collected, Rabka appears to be the best candidate for small-scale boron production in terms of boron content and water resources values.
\end{abstract}

Keywords: borate; high content of boron in water; curative water in Poland

\section{Introduction}

The boron content in the lithosphere is relatively high. The value of the boron concentration in the continental crust is on average $10 \mathrm{mg} / \mathrm{kg}$. Boron does not exist in nature as a pure element. It is found in bonded form [1,2]. There are over 200 different boron minerals in nature. Commercially, the most important boron minerals are compounds containing boron oxide in varying proportions, i.e., tincal (borax) $\left(\mathrm{Na}_{2} \mathrm{~B}_{4} \mathrm{O}_{7} .10 \mathrm{H}_{2} \mathrm{O}\right)$, kernite $\left(\mathrm{Na}_{2} \mathrm{~B}_{4} \mathrm{O}_{7} \cdot 4 \mathrm{H}_{2} \mathrm{O}\right)$, colemanite $\left(\mathrm{Ca}_{2} \mathrm{~B}_{6} \mathrm{O}_{11} \cdot 5 \mathrm{H}_{2} \mathrm{O}\right)$, ulexite $\left(\mathrm{NaCaB}_{5} \mathrm{O}_{9} .8 \mathrm{H}_{2} \mathrm{O}\right)$, hydroboracite $\left(\mathrm{CaMgB}_{6} \mathrm{O}_{11} .6 \mathrm{H}_{2} \mathrm{O}\right)$, boracite $\left(\mathrm{Mg}_{3} \mathrm{~B}_{7} \mathrm{O}_{13} \mathrm{Cl}\right)$, pandermite $\left(\mathrm{Ca}_{4} \mathrm{~B}_{10} \mathrm{O}_{19} .7 \mathrm{H}_{2} \mathrm{O}\right)$ and szaibelyite (ascharite) $\left(\mathrm{Mg}_{2} \mathrm{~B}_{2} \mathrm{O}_{5} \cdot \mathrm{H}_{2} \mathrm{O}\right)[3,4]$. However, today, borax is the most important mineral for the borate industry. Borax occurs in the largest exogenous boron deposits in the world (Boron, California; Kyrka, Turkey; and Tincalayu, Argentina) [5]. Most commercial borate deposits in the world are exploited by opencast mining. Boron is also obtained from 
the brine from Searles Lake (USA) and Chinese sources via controlled evaporation or carbonation [6,7].

In the hydrosphere, the main reservoir of boron is seawater, which has an average content of $4.5 \mathrm{mg} / \mathrm{L}[2,8]$. This is because marine clays are richer in boron than other types of rock [9]. In most groundwater, typical boron concentrations are below $1.0 \mathrm{mg} / \mathrm{L}$ [2]. A natural source of boron in groundwater is leaching from rocks and soils containing borates and borosilicates [10]. Boron enrichment also occurs as a result of human activity (industry, agriculture, detergents that contain sodium perborate); therefore, water and sewage may contain boron of anthropogenic origin from several to several dozen milligrams per liter [11].

Due to the wide use and demand for boron, sources other than borate deposits are sought. It is well known that there are numerous boron-rich brines in the world, such as salt lake brines, oil field waters, and various types of underground brines [12]. To date, many methods have been developed to separate boron from aqueous solutions, i.e., fresh water and different types of brines and sewage $[12,13]$. The topic of boron recovery from thermal waters has already been discussed in Poland [14,15]. Various methods of obtaining boron from aqueous solutions are found not only in the literature but also in patents [16-20]. These methods have been tested on a laboratory scale, but some have also been field tested [21]. Methods based on ion exchange and adsorption processes are usually suitable for waters with low boron concentration [22,23]. Reverse osmosis has been extensively tested in desalination $[23,24]$. The precipitation methods are instead used in aqueous solutions with higher boron content [24].

However, so far, there are no widely used methods for recovering boron from aqueous solution. The main problem is the complex chemistry of boron and the fact that known boron extraction methods are relatively expensive [21]. From an economic point of view, a valuable boron concentration in brine is above $100 \mathrm{ppm}$ [14].

Boric acid and borate ion are two dominant forms of inorganic boron in natural aqueous systems. The $\mathrm{pK}$ value $(\mathrm{pK}=-\log \mathrm{K})$ of boric acid varies depending on $\mathrm{pH}$, ionic strength, and temperature of the solution, where $\mathrm{K}$ is equilibrium constant of the reaction:

$$
\mathrm{H}_{3} \mathrm{BO}_{3}+\mathrm{H}_{2} \mathrm{O} \leftrightarrow \mathrm{B}(\mathrm{OH})_{4}{ }^{-}+\mathrm{H}^{+}
$$

For example, the value of $\mathrm{pK}$ is 9.24 at $25^{\circ} \mathrm{C}$ in fresh waters [25]. On the other hand, for seawater with a salinity of $35 \%$, the value of $\mathrm{pK}$ at $10{ }^{\circ} \mathrm{C}$ is 8.76 , and at $35{ }^{\circ} \mathrm{C}$ it is $8.47[26,27]$. Nevertheless, the $\mathrm{pH}$ of the aqueous solution is the most significant parameter which determines the ratio of undissociated boric acid to borate ions in water. Depending on the boron concentration in water, various boron-containing species may be found. Low and medium concentrations of boron occur in the aqueous environment as boric acid $\mathrm{H}_{3} \mathrm{BO}_{3}\left(\mathrm{~B}(\mathrm{OH})_{3}\right)$ or borate ion $\mathrm{B}(\mathrm{OH})_{4}{ }^{-}$[28]. The distribution of two dominant forms of inorganic boron in natural aqueous systems versus $\mathrm{pH}$ is presented in Figure 1a. Watersoluble polyborate ions, i.e., $\mathrm{B}_{3} \mathrm{O}_{3}(\mathrm{OH})_{4}{ }^{-}, \mathrm{B}_{4} \mathrm{O}_{5}(\mathrm{OH})_{4}{ }^{-}, \mathrm{B}_{3} \mathrm{O}_{3}(\mathrm{OH})_{5}{ }^{-}$and $\mathrm{B}_{5} \mathrm{O}_{6}(\mathrm{OH})_{4}{ }^{-}$are formed at higher concentrations of boron in water in the $\mathrm{pH}$ range of 6-12 [25]. However, the formation of polyborate ions is negligible when the boron concentration in the aqueous solution is below $290 \mathrm{mg} / \mathrm{L}$ [29].

Boron is a valued raw material in industry, primarily for glass, ceramics, agriculture and household chemicals (Figure 1b, [30]). Currently, the industrial demand for this element is growing due to the development of modern architecture (fiberglass insulation materials, flame retardants). A significant demand for raw boron materials also results from the development of electronics, telecommunications (LCD screens), and the automotive, aviation and energy industries [4]. The price of raw boron materials increases with the increase in market demand. The chart shows a predicted continuous increase in the price of raw boron materials in the coming years (Figure 2a, [31]). 


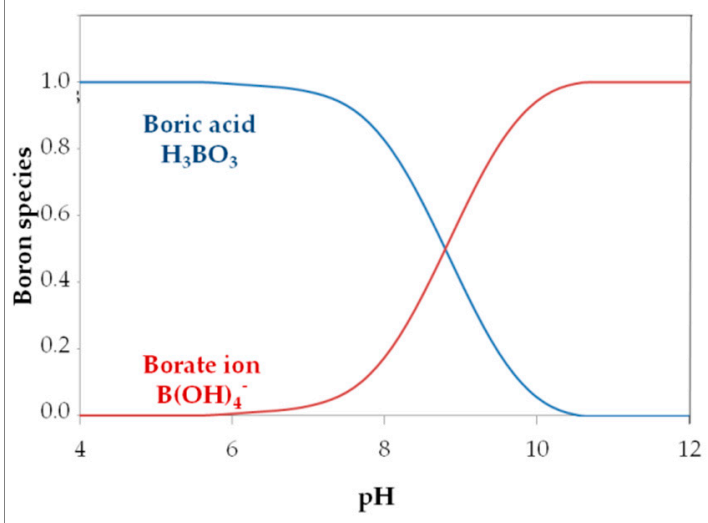

(a)

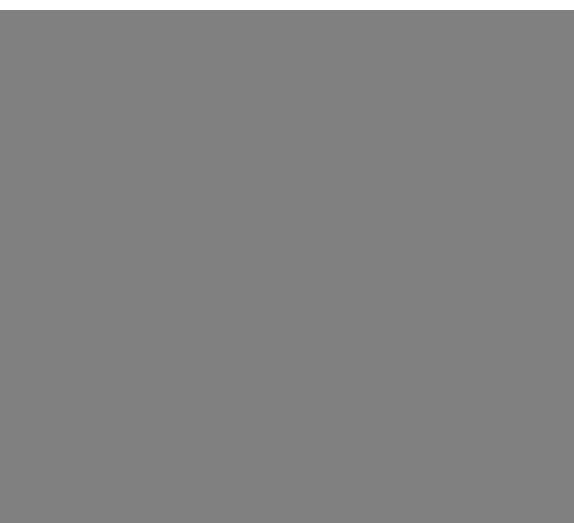

(b)

Figure 1. (a) The distribution of two dominant forms of inorganic boron in natural aqueous systems versus $\mathrm{pH}$ [26], (b) global boron end-use share by application [30].

Since 2014, borates have been classified by the European Union as critical raw materials. In 2008, the European Commission initiated activities aimed at creating a collective raw materials policy [32]. As part of these activities, a list of critical raw materials has been published every three years since 2011. The list contains raw materials of very high economic importance, the supplies of which are at risk of shortage. The EU is $100 \%$ dependent on imported borates. Turkey, which has the largest boron deposits in the world, supplies $98 \%$ of this element to the EU market (Figure 2b, [33]).

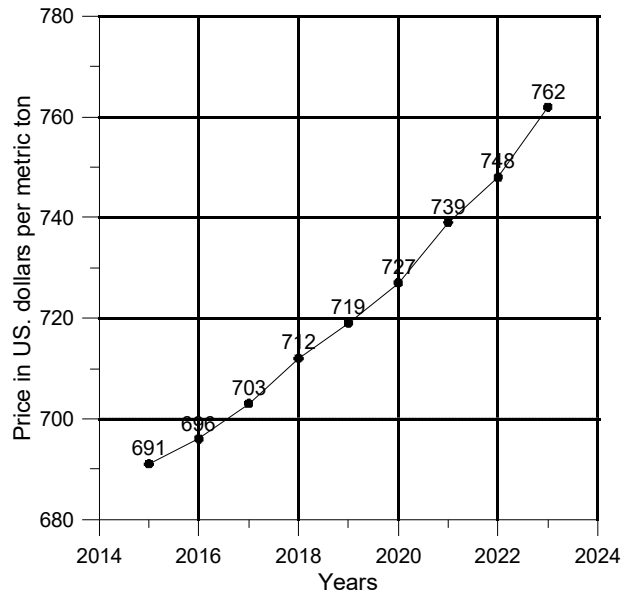

(a)

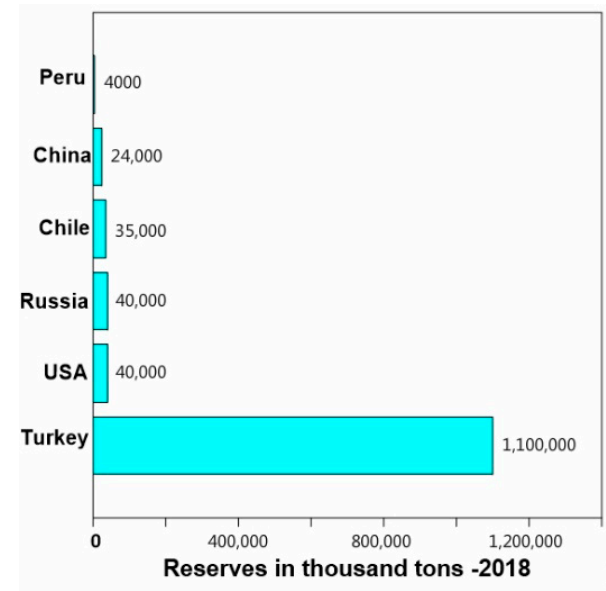

(b)

Figure 2. (a) Medium-term forecast for boric acid prices worldwide from 2015 to 2023 [31], (b) world boron reserves as of 2019, by major countries [33].

Statistics from 2019 indicate that Turkey is the largest producer of boron minerals in the world (2500 thousand metric tons). Chile, China and Bolivia are next, with productions of 400, 250 and 210 thousand metric tons, respectively [34,35]. The list of the world's 10 largest producers of boron minerals also includes Argentina, Peru, Russia, Kazakhstan, and, since 2018, Germany. The United States is certainly also one of the top ten producers of boron minerals. However, the US data is currently withheld and not included in the total world mining production. For example, US boron mineral production in 2005 and 2010 was 1230 and 1150 thousand metric tons, respectively, while the production of boron minerals in Turkey in 2005 and 2010 was 1700 and 1850 thousand metric tons, respectively [36,37].

Globally, borates are not considered a critical raw material or are referred to as a moderate resource scarcity mineral [38-41]. However, projections based on increasing 
market demand for borates indicate that "non-critical boron minerals" could become "highly critical" within 70 years [38].

The therapeutic properties of various waters used in numerous spas have been proven by long-standing medical observations and by clinical research. In 1911, the first European classification of medicinal waters was introduced. This classification resulted from the recognized pharmaco-dynamic factors of individual specific water components. The minimum concentration values of these specific components in therapeutic groundwater are presented in Table 1. However, including water with an appropriate physico-chemical composition in the category of therapeutic waters depends on obtaining a certificate and administrative decisions. In Poland, the quality of therapeutic waters is controlled by the Polish Institute of Hygiene.

In the first balneological classification, which was adopted at the First International Balneological Congress in Nauheim in 1911 and then supplemented in 1934 in Salzuflen, an $\mathrm{HBO}_{2}$ concentration of $5 \mathrm{mg} / \mathrm{L}$ was defined as the limit above which water was classified as therapeutic. The antiseptic effect of water with $\mathrm{HBO}_{2}$ concentrations above $5 \mathrm{~g} / \mathrm{L}$ was observed [42,43]. In Poland, boron has had the status of a specific component of curative water since the first classification was proposed by Maria Szmytówna and adopted at the Congress of the Polish Balneological Society in Inowrocław in 1956. Currently (since 2006 [44]), the Polish Geological and Mining Law [45] does not define boron water, because recent reports show that high doses of boron may be harmful to human health. According to Nielsen [46], the lethal dose of boron is $3 \mathrm{~g}$ for infants and 15-29 $\mathrm{g}$ for adults. The European Union recommends $1.0 \mathrm{mg} / \mathrm{L}$ as a safe concentration of boron in water intended for human consumption $[47,48]$. The fact that the concentration of boron exceeds the allowed values in some curative waters of Poland has already been discussed [49-51]. However, while currently metaboric acid is not a specific component of the healing waters, it is present at detectable concentrations in many waters considered therapeutic based on the other specific components listed in Table 1. However, despite the fact that metaboric acid is not currently a specific component of curative waters, it is present in detectable concentrations in many waters with increased mineralization, including those considered therapeutic on the basis of other specific components.

Table 1. Criteria for classification of medicinal waters.

\begin{tabular}{|c|c|c|c|}
\hline \multirow[t]{2}{*}{ Name of Waters (Specific Component) } & \multicolumn{3}{|c|}{$\begin{array}{l}\text { The Minimum Concentration Value of the Specific Component for } \\
\text { Groundwater with Content of Dissolved Solid Minerals of at Least } 1 \mathrm{~g} / \mathrm{L}\end{array}$} \\
\hline & $\begin{array}{l}1911 \\
\text { (Europe) }\end{array}$ & $\begin{array}{l}1956 \\
\text { (Poland) }\end{array}$ & $\begin{array}{l}2006 \\
\text { (Poland) }\end{array}$ \\
\hline Ferruginous waters $\left(\mathrm{Fe}^{2+}\right)$ & $10 \mathrm{mg} / \mathrm{L}$ & $10 \mathrm{mg} / \mathrm{L}$ & $10 \mathrm{mg} / \mathrm{L}$ \\
\hline Fluoride waters $\left(\mathrm{F}^{-}\right)$ & $2 \mathrm{mg} / \mathrm{L}$ & $1 \mathrm{mg} / \mathrm{L}$ & $2 \mathrm{mg} / \mathrm{L}$ \\
\hline Iodide waters $\left(\mathrm{J}^{-}\right)$ & $1 \mathrm{mg} / \mathrm{L}$ & $1 \mathrm{mg} / \mathrm{L}$ & $1 \mathrm{mg} / \mathrm{L}$ \\
\hline Bromide waters $\left(\mathrm{Br}^{-}\right)$ & $5 \mathrm{mg} / \mathrm{L}$ & $5 \mathrm{mg} / \mathrm{L}$ & * \\
\hline Sulfide waters $\left(\mathrm{S}^{\mathrm{II}}\right)$ & $1 \mathrm{mg} / \mathrm{L}$ & $1 \mathrm{mg} / \mathrm{L}$ & $1 \mathrm{mg} / \mathrm{L}$ \\
\hline Silica waters $\left(\mathrm{H}_{2} \mathrm{SiO}_{3}\right)$ & $50 \mathrm{mg} / \mathrm{L}$ & $100 \mathrm{mg} / \mathrm{L}$ & $70 \mathrm{mg} / \mathrm{L}$ \\
\hline Radon or radioactive waters ( $\mathrm{Rn})$ & $1 \mathrm{pCi}\left(37 \mathrm{~Bq} / \mathrm{m}^{3}\right)$ & $2 \mathrm{pCi}\left(37 \mathrm{~Bq} / \mathrm{m}^{3}\right)$ & $2 \mathrm{pCi}\left(74 \mathrm{~Bq} / \mathrm{m}^{3}\right)$ \\
\hline Arsenic waters (arsenic, As ${ }^{\mathrm{III}} / \mathrm{As}^{\mathrm{V}}$ ) & $0.2 \mathrm{mg} / \mathrm{L}$ & $0.7 \mathrm{mg} / \mathrm{L}$ & * \\
\hline Boric waters $\left(\mathrm{HBO}_{2}\right)$ & $5 \mathrm{mg} / \mathrm{L}$ & $5 \mathrm{mg} / \mathrm{L}$ & * \\
\hline Carbonated waters $\left(\mathrm{CO}_{2}\right)$ & not established & $250 \mathrm{mg} / \mathrm{L}$ & $250 \mathrm{mg} / \mathrm{L}$ \\
\hline $\mathrm{CO}_{2}$ reach waters $\left(\mathrm{CO}_{2}\right)($ Carbonated water $)$ & not established & $1000 \mathrm{mg} / \mathrm{L}$ & $1000 \mathrm{mg} / \mathrm{L}$ \\
\hline
\end{tabular}

II and III, V_oxidation states of sulfur and arsenic atom, * not defined by the Polish Geological and Mining Law.

In summary, high boron content in water can be both an advantage and a disadvantage. Medicinal water with high boron content that is used for therapy can be a problem for spas, but high boron content in water provides great opportunities for obtaining borate, which is classified by the EU as a critical raw mineral. The main aim of this study is to highlight the high content of boron in curative water and potentially consider it as a source of boron for 
industrial applications. For this purpose, the set of data on physico-chemical parameters of curative waters from various available sources (scientific articles, certificates confirming the healing properties of water and research conducted for health resorts by the Faculty of Petroleum Engineering of the AGH University of Science and Technology) was collected. This made it possible to systematize the data on the content of boron in Polish curative waters. This is the first comprehensive report of this type. The result is information about the location of medicinal waters with high boron content in Poland. These data can be used to discuss the possible harmfulness of high boron content in curative waters. The collected dataset can also be useful when considering the prospects of boron recovery from these waters, especially since no boron minerals are mined or produced in Poland.

\section{Materials and Methods}

\subsection{Geological Setting}

In terms of geological structure and hydrogeological conditions, Poland is divided into four areas: Precambrian Platform, Palaeozoic Platform, Sudetes and Carpathians [52,53]. These units are then divided into smaller regions. Precambrian platform and Paleozoic platform cover the area of the Polish Lowlands. In the platform areas, mineral waters mainly occur in Cretaceous, Jurassic and Triassic formations. The Sudetes area is a complex of structural mosaics that were shaped, predominantly, during the Variscan orogeny. There are various types of geological units built of different rocks: magmatic, metamorphic and sedimentary series. The Carpathians province includes the Outer Carpathians, the Inner Carpathians, Pieniny Klippen Belt and the Carpathian Foredeep. The Outer Carpathians are composed of Cretaceous and Paleogene flysch formations (shales and sandstones). These rocks were overthrust from the south and folded in several orogenic cycles in the Paleogene and Neogene through to the late Miocene. The Carpathian Foredeep is a part of the large sedimentary basin linked with Alpine Molasse basin filled with predominantly clastic sediments of the Miocene age. The characteristic feature of the area is evaporates (gypsum, anhydrite and salt). These chemical sediments have an impact on the chemistry of the groundwater. More details about the geological structure of Poland linked with therapeutic waters can be found in [53]. The majority of water used for balneotherapy is found in the Sudetes and the Carpathians.

\subsection{Physico-Chemical Parameters of Curative Waters}

There are underground waters almost all over Poland that are characterized by mineralization of at least $1.0 \mathrm{~g} / \mathrm{L}$ or the content of specific components in concentrations adopted for medicinal waters. These waters are used for treatment by drinking, bathing, and as a medicinal aerosol in graduation towers. These curative waters are exploited in Polish spas and towns without the status of health resorts. The names of 248 analyzed water intakes and their physico-chemical data are presented in Table S1 (Supplementary Materials). Of the data on the physico-chemical parameters of these waters come from published data (scientific articles), collected certificates confirming the therapeutic properties of these waters, and research carried out by Lewkiewicz-Małysa et al. for health resorts by the Faculty of Petroleum Engineering of AGH University of Science and Technology (unpublished data) [54-77].

\subsection{Statistical Analysis}

The relationship between boron concentration and other water parameters was investigated for the whole dataset. It should be noted that the set of available chemical parameters for the tested waters was different. Analyses were carried out in spas in order to obtain certificates confirming the healing properties of water contain detailed information about the composition of the waters. On the other hand, the analyses found in scientific publications typically contain information on the concentration of main ions and specific components. Therefore, the correlation analysis was limited to those components for which sufficient data was collected (for major ions: $\mathrm{Na}^{+}, \mathrm{Ca}^{2+}, \mathrm{Mg}^{2+}, \mathrm{Cl}^{-}, \mathrm{SO}_{4}{ }^{2-}, \mathrm{CO}_{3}{ }^{2-}$ and $\mathrm{HCO}_{3}{ }^{-}$). 
Data analysis was performed using the Statistica 13.1 program. First, the graphical point distributions were analyzed, and then the linear correlation coefficients were calculated. The values of Pearson's correlation coefficient that were statistically significant and indicated a strong correlation $(r>0.7)$ are discussed in the text. The figures include graphs that show the strong correlation between the water parameters. The graphs are presented on a logarithmic scale in order to better visualize a large amount of data with high variability of values.

\section{Results}

The intakes of the curative waters are presented against the background of geological units in Poland [52] in Figure 3. The research collection included 248 curative waters from both natural sources (springs) and boreholes in various geological regions of Poland. The map (Figure 3) shows 51 locations (30 of which are health resorts), and the colors of the points indicate different boron levels in the investigated waters. Red points indicate boron concentrations up to $5 \mathrm{mg} / \mathrm{L}$; blue indicates concentrations between 5 and $25 \mathrm{mg} / \mathrm{L}$; green denotes concentrations above $25 \mathrm{mg} / \mathrm{L}$. Moreover, the data for curative waters with boron concentrations above $25 \mathrm{mg} / \mathrm{L}$ (location, name of water intake, and selected physicochemical parameters) are presented in Table 2.

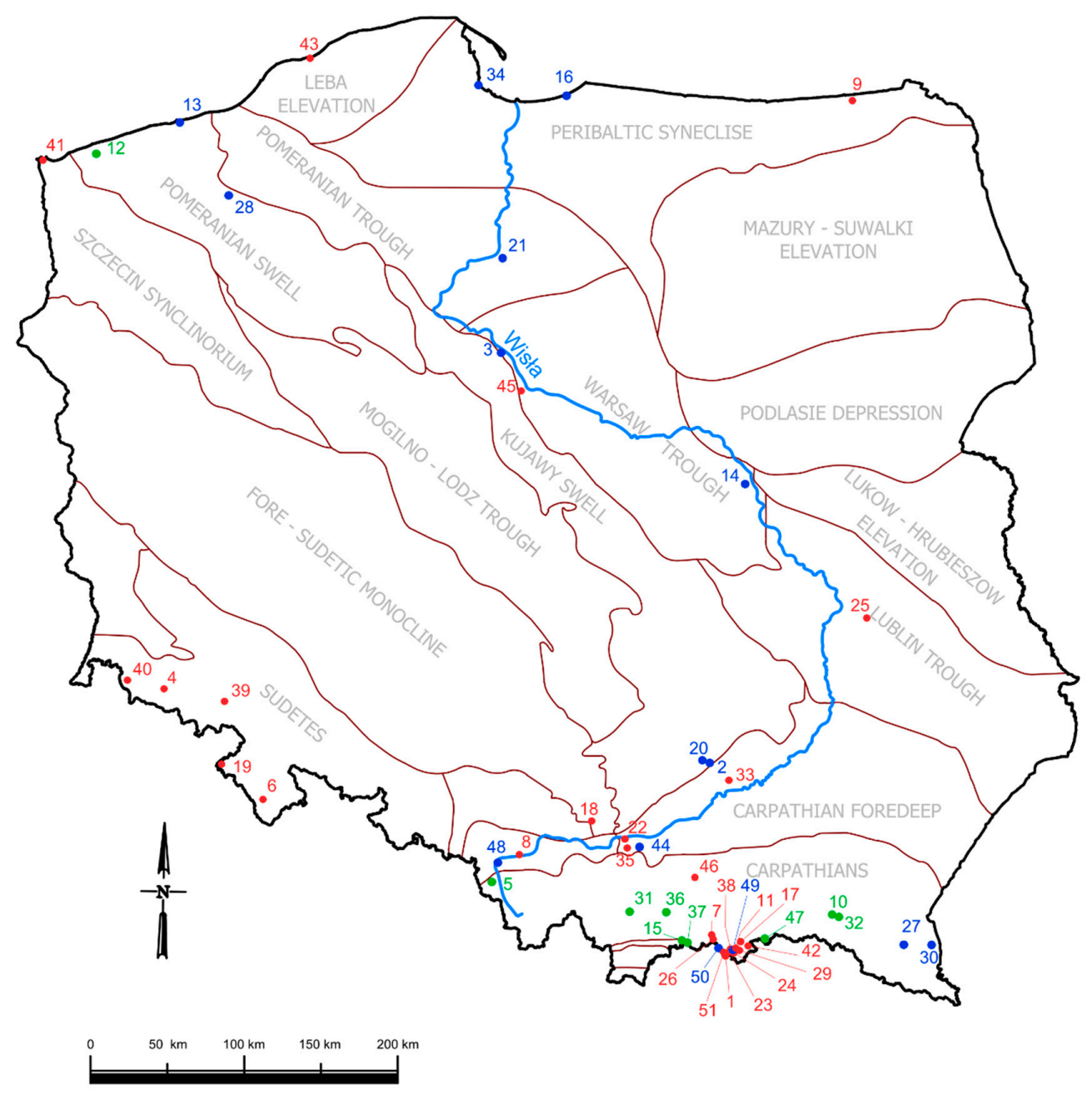

Figure 3. Locations of the investigated curative water on the background of main tectonic structures $(\bullet \mathrm{red} \leq 5 \mathrm{mg} / \mathrm{L} ; \bullet \mathrm{blue}$ $>5$ and $\leq 25 \mathrm{mg} / \mathrm{L} ; \bullet$ green color $>25 \mathrm{mg}$ /L of boron). 1-Andrzejówka, 2-Busko-Zdrój, 3-Ciechocinek, 4-Jelenia Góra (Cieplice Śląskie-Zdrój), 5-Dębowiec 6-Długopole-Zdrój, 7—Głębokie, 8-Goczałkowice-Zdrój, 9-Gołdap, 10-IwoniczZdrój, 11—Jastrzębik, 12-Kamień Pomorski, 13-Kołobrzeg, 14-Konstancin-Jeziorna, 15—Krościenko nad Dunajcem, 16-Krynica Morska, 17—Krynica-Zdrój, 18—Krzeszowice, 19-Kudowa-Zdrój, 20—Las Winiarski, 21—Marusza, 22- 
Kraków (Mateczny), 23-Milik, 24-Muszyna, 25-Nałęczów, 26-Piwniczna-Zdrój, 27-Polańczyk, 28-Połczyn-Zdrój, 29Powroźnik, 30-Rabe, 31- Rabka-Zdrój, 32-Rymanów-Zdrój, 33-Solec-Zdrój, 34-Sopot, 35-Kraków (Swoszowice), 36-Szczawa, 37-Szczawnica, 38-Szczawnik, 39-Szczawno-Zdrój, 40-Świeradów-Zdrój, 41—Świnoujście, 42—Tylicz, 43-Ustka, 44-Wieliczka, 45-Wieniec-Zdrój, 46-Wojkowa, 47-Wysowa-Zdrój, 48-Zabłocie, 49—Złockie, 50—Zubrzyk, 51-Żegiestów-Zdrój.

Table 2. Curative waters with boron concentrations above $25 \mathrm{mg} / \mathrm{L}$.

\begin{tabular}{|c|c|c|c|c|c|c|c|}
\hline Location & $\begin{array}{c}\text { Name } \\
\text { of Water Intake }\end{array}$ & TDS & $\mathrm{pH}$ & $\begin{array}{l}\text { Type of } \\
\text { Water }\end{array}$ & $\begin{array}{l}\mathrm{HBO}_{2} \\
(\mathrm{mg} / \mathrm{L})\end{array}$ & $\begin{array}{c}\text { B } \\
(\mathrm{mg} / \mathrm{L})\end{array}$ & Ref. \\
\hline Dębowiec & D-2 & $32,398.37$ & 6.72 & $\mathrm{Cl}-\mathrm{Na}$ & 110.24 & 27.22 & [61] \\
\hline Iwonicz & Zofia 6 & $11,066.00$ & 7.26 & $\mathrm{Cl}-\mathrm{HCO}_{3}-\mathrm{Na}$ & 168.00 & 41.48 & [58] \\
\hline Iwonicz & Lubatówka 12 & $19,676.00$ & 7.32 & $\mathrm{Cl}-\mathrm{HCO}_{3}-\mathrm{Na}$ & 157.50 & 38.89 & [58] \\
\hline Iwonicz & Lubatówka 15 & $15,717.97$ & 7.62 & $\mathrm{Cl}-\mathrm{HCO}_{3}-\mathrm{Na}$ & 255.34 & 63.05 & [58] \\
\hline Iwonicz & Zofia 3 & $12,263.53$ & 7.60 & $\mathrm{Cl}-\mathrm{HCO}_{3}-\mathrm{Na}$ & 226.97 & 56.04 & [58] \\
\hline $\begin{array}{c}\text { Kamień } \\
\text { Pomorski }\end{array}$ & Edward II & $35,016.54$ & 6.35 & $\mathrm{Cl}-\mathrm{Na}$ & 110.24 & 27.22 & [61] \\
\hline Krościenko & Stefan & 7317.40 & 9.70 & $\mathrm{HCO} 3-\mathrm{Cl}-\mathrm{Na}$ & 162.80 & 40.20 & [54] \\
\hline Krościenko & Michalina & 8558.50 & 6.50 & $\mathrm{HCO} 3-\mathrm{Cl}-\mathrm{Na}$ & 233.30 & 57.60 & [54] \\
\hline Rabka & Krakus & $24,806.64$ & 7.53 & $\mathrm{Cl}-\mathrm{Na}$ & 418.07 & 103.23 & [72] \\
\hline Rabka & Rafaela & $24,138.00$ & 6.60 & $\mathrm{Cl}-\mathrm{Na}$ & 522.80 & 129.09 & [72] \\
\hline Rabka & Warzelnia & 9101.54 & 7.81 & $\mathrm{Cl}-\mathrm{Na}$ & 195.90 & 48.37 & [58] \\
\hline Rabka & Bolesław & $23,219.00$ & 6.50 & $\mathrm{Cl}-\mathrm{Na}$ & 483.90 & 119.48 & [72] \\
\hline Rabka & Helena & $17,924.17$ & 8.46 & $\mathrm{Cl}-\mathrm{Na}$ & 133.17 & 32.88 & [58] \\
\hline Rabka & Rabka 18 & $25,504.95$ & 7.40 & $\mathrm{Cl}-\mathrm{Na}$ & 440.78 & 108.83 & [58] \\
\hline Rabka & Rabka 19 & 19765.74 & 7.85 & $\mathrm{Cl}-\mathrm{Na}$ & 210.37 & 51.94 & [58] \\
\hline Rabka & Rabka IG-1 & $21,993.20$ & 6.50 & $\mathrm{Cl}-\mathrm{Na}$ & 339.20 & 83.75 & [72] \\
\hline Rabka & Rabka IG-II & $25,596.12$ & 7.50 & $\mathrm{Cl}-\mathrm{Na}$ & 547.43 & 135.17 & [58] \\
\hline Rymanów & RZ-1 & $22,643.00$ & 7.11 & $\mathrm{Cl}-\mathrm{Na}$ & 208.10 & 51.38 & [58] \\
\hline Rymanów & $\mathrm{RZ}-2$ & 9279.00 & 7.52 & $\mathrm{HCO} 3-\mathrm{Cl}-\mathrm{Na}$ & 128.10 & 31.63 & [58] \\
\hline Rymanów & Ignacy & 4312.00 & 6.95 & $\mathrm{Cl}-\mathrm{HCO}_{3}-\mathrm{Na}$ & 101.82 & 25.14 & [58] \\
\hline Rymanów & RZ-4 (IG-1) & 6466.00 & 7.14 & $\mathrm{Cl}-\mathrm{HCO}_{3}-\mathrm{Na}$ & 126.60 & 31.26 & [58] \\
\hline Rymanów & RZ-6 & 6126.00 & 6.95 & $\mathrm{Cl}-\mathrm{HCO}_{3}-\mathrm{Na}$ & 102.71 & 25.36 & [58] \\
\hline Rymanów & Celestyna & 8207.00 & 6.67 & $\mathrm{Cl}-\mathrm{HCO}_{3}-\mathrm{Na}$ & 162.67 & 40.17 & [58] \\
\hline Rymanów & Klaudia & 7724.00 & 6.44 & $\mathrm{Cl}-\mathrm{HCO}_{3}-\mathrm{Na}$ & 157.42 & 38.87 & [58] \\
\hline Rymanów & Tytus & 7981.00 & 6.42 & $\mathrm{Cl}-\mathrm{HCO}_{3}-\mathrm{Na}$ & 146.43 & 36.16 & [58] \\
\hline Rymanów & Basenowe & 7446.00 & 6.38 & $\mathrm{Cl}-\mathrm{HCO}_{3}-\mathrm{Na}$ & 140.38 & 34.66 & [58] \\
\hline Szczawa & Szczawa I & $17,287.00$ & 6.63 & $\mathrm{HCO}_{3}-\mathrm{Cl}-\mathrm{Na}$ & 494.00 & 121.98 & [58] \\
\hline Szczawa & Szczawa II & $22,227.00$ & 6.73 & $\mathrm{HCO}_{3}-\mathrm{Cl}-\mathrm{Na}$ & 459.00 & 113.33 & [58] \\
\hline Szczawa & Dziedzilla & 5135.70 & 6.30 & $\mathrm{HCO}_{3}-\mathrm{Cl}-\mathrm{Na}$ & 145.00 & 35.80 & [54] \\
\hline Szczawa & Hanna & 5460.00 & 6.00 & $\mathrm{HCO}_{3}-\mathrm{Cl}-\mathrm{Na}$ & 190.90 & 47.14 & [54] \\
\hline Szczawa & Krystyna & $12,691.00$ & 6.70 & $\mathrm{HCO}_{3}-\mathrm{Cl}-\mathrm{Na}$ & 227.00 & 56.05 & [54] \\
\hline Szczawnica & Magdalena & $25,849.00$ & 6.79 & $\mathrm{HCO}_{3}-\mathrm{Cl}-\mathrm{Na}$ & 599.30 & 147.98 & [58] \\
\hline Szczawnica & Wanda & 6707.00 & 6.49 & $\mathrm{HCO}_{3}-\mathrm{Cl}-\mathrm{Na}$ & 144.00 & 35.56 & [58] \\
\hline Szczawnica & Stefan II (Dzikie) & 6913.00 & 6.09 & $\mathrm{HCO}_{3}-\mathrm{Cl}-\mathrm{Na}$ & 192.00 & 47.41 & [61] \\
\hline Szczawnica & Józef (B-4) & $11,722.00$ & 6.30 & $\mathrm{HCO}_{3}-\mathrm{Cl}-\mathrm{Na}$ & 268.20 & 66.22 & [58] \\
\hline Wysowa & Aleksandra & $23,751.00$ & 6.89 & $\mathrm{HCO}_{3}-\mathrm{Cl}-\mathrm{Na}$ & 760.00 & 187.65 & [58] \\
\hline Wysowa & Józef II & 4991.00 & 6.23 & $\mathrm{HCO}_{3}-\mathrm{Cl}-\mathrm{Na}$ & 150.60 & 37.19 & [58] \\
\hline Wysowa & W-11 (Henryk) & 5225.00 & 6.46 & $\mathrm{HCO}_{3}-\mathrm{Cl}-\mathrm{Na}$ & 177.70 & 43.88 & [58] \\
\hline Wysowa & $\mathrm{W}-15$ & 6166.00 & 6.34 & $\mathrm{HCO}_{3}-\mathrm{Cl}-\mathrm{Na}$ & 197.00 & 48.64 & [58] \\
\hline Wysowa & W-13 (Anna) & $11,715.00$ & 6.53 & $\mathrm{HCO}_{3}-\mathrm{Cl}-\mathrm{Na}$ & 367.00 & 90.62 & [58] \\
\hline Wysowa & W14(Franciszek) & $14,448.00$ & 6.72 & $\mathrm{HCO}_{3}-\mathrm{Cl}-\mathrm{Na}$ & 448.50 & 110.74 & [58] \\
\hline Wysowa & W-16 & 6523.00 & 7.20 & $\mathrm{HCO}_{3}-\mathrm{Cl}-\mathrm{Na}$ & 170.10 & 42.00 & [58] \\
\hline
\end{tabular}

The tested waters were either two-ionic or multi-ionic. They were divided into groups according to the Szczukariew-Prikłoński classification that is used for medicinal waters. The type of water was determined on the basis of the content of ions above $20 \%$ milivals. The datasets for each water type were different (from 1 to 50). Therefore, some waters classified as having similar ionic compositions (although they were not in the same group 
according to the Szczukariew-Prikłoński classification) were grouped together. Groups with only one type of water according to the Szczukariew-Prikłoński classification (i.e., $\mathrm{Cl}-\mathrm{Na}, \mathrm{Cl}-\mathrm{HCO}_{3}-\mathrm{Na}$ and $\mathrm{HCO}_{3}-\mathrm{Cl}-\mathrm{Na}$ ) and groups with similar water types were created. The group of waters designated by us as $\mathrm{SO}_{4}$ comprised waters in which the $\mathrm{SO}_{4}$ ion was present in an amount greater than $20 \%$ milivals. This is, in fact, the group of waters categorized by the Szczukariew-Prikłoński classification as types $\mathrm{Cl}-\mathrm{SO}_{4}-\mathrm{Na}, \mathrm{SO}_{4}-\mathrm{Cl}-\mathrm{Ca}$ $\mathrm{Na}, \mathrm{SO}_{4}-\mathrm{Cl}-\mathrm{HCO}_{3}-\mathrm{Mg}, \mathrm{SO}_{4}-\mathrm{HCO}_{3}-\mathrm{Na}, \mathrm{SO}_{4}-\mathrm{HCO}_{3}-\mathrm{Ca}-\mathrm{Mg}, \mathrm{SO}_{4}-\mathrm{HCO}_{3}-\mathrm{Cl}-\mathrm{Na}, \mathrm{SO}_{4}-\mathrm{Ca}$ and $\mathrm{SO}_{4}-\mathrm{Ca}-\mathrm{Mg}$. On the other hand, in the group we called $\mathrm{HCO}_{3}-\mathrm{Ca}(\mathrm{Mg}-\mathrm{Na})$, there were also waters of the types $\mathrm{HCO}_{3}-\mathrm{Ca}-\mathrm{Mg}$ and $\mathrm{HCO}_{3}-\mathrm{Mg}-\mathrm{Na}$ (according to the SzczukariewPrikłoński classification).

The analyzed waters belonging to the $\mathrm{Cl}-\mathrm{Na}$ type occurred in the sedimentary covers of the Precambrian and Palaeozoic platforms (Triassic, Jurassic and Cretaceous sandstones). The mineralization increases with the depth of the aquifers and ranges from 3 to $79 \mathrm{~g} / \mathrm{L}$. The waters of the Cl-Na type form a small group among the Carpathian mineral waters; their mineralization ranges from 9 to $146 \mathrm{~g} / \mathrm{L}$, and in the Carpathian Foredeep (their mineralization ranges from 6.8 to $79 \mathrm{~g} / \mathrm{L}$ ). The complicated geological structure results in the mineralization of the waters not b3ing correlated with the depth of the deposits in which these waters occur.

Healing waters of the $\mathrm{HCO}_{3}-\mathrm{Ca}(\mathrm{Mg}, \mathrm{Na})$ type, including carbonated waters, are found in the Sudetes and Carpathians. In the Sudetes, they occur in Precambrian rocks (mica shales, granite gneisses), and in Szczawno they flow from fissure springs from Lower Cambrian sandstones. Mineralization of these waters ranges from 0.6 to $3.8 \mathrm{~g} / \mathrm{L}$. In the Carpathians, waters of the $\mathrm{HCO}_{3}-\mathrm{Ca}(\mathrm{Mg}$, Na) type occur in Cenozoic (PalaeogeneNeogene) formations, and their mineralization ranges from 0.6 to $25 \mathrm{~g} / \mathrm{L}$. Waters of $\mathrm{HCO}_{3}$ $\mathrm{Cl}-\mathrm{Na}$ type occur in the Carpathians. Their mineralization ranges from 1 to $15 \mathrm{~g} / \mathrm{L}$. In the area of Rymanów and Iwonicz there are $\mathrm{Cl}-\mathrm{HCO}_{3}-\mathrm{Ca}$ type waters with mineralization from 6 to $20 \mathrm{~g} / \mathrm{L}$. Waters of the " $\mathrm{SO}_{4}$ " type occur in the area of the Carpathian Foredeep. These are waters of types $\mathrm{SO}_{4}-\mathrm{Cl}-\mathrm{Na}(\mathrm{Mg}, \mathrm{Ca})$ and $\mathrm{Cl}_{-} \mathrm{SO}_{4}-\mathrm{Na}$ with mineralization from 2.3 to $17 \mathrm{~g} / \mathrm{L}$. In the Busko-Zdrój region, they occur in cenonomann sands and sandstones and kimerite marls, and in the area of Krakow in the sandstones and marls of PalaeogeneNeogene formations (Krzeszowice) and Miocene gypsum (Krakow-Mateczny). Outside the Carpathians, the list also includes waters of the $\mathrm{SO}_{4}-\mathrm{HCO}_{3}(\mathrm{Cl})$ type (thermal waters occurring in the dislocated Lower Carboniferous granites in Jelenia Góra-Cieplice (Sudetes). Mineralization of these waters ranges from 0.6 to $3.8 \mathrm{~g} / \mathrm{L}$.

When interpreting the relationship between the chemical parameters of waters, it should be remembered that the analyzed data set is a heterogeneous set. Cl-Na type waters come from a large area of Poland (all hydrogeological provinces), and deposits lying from a few meters to over $1000 \mathrm{~m}$. Waters of other groups (divided according to the Szczukariew-Prikłoński classification) come from shallower aquifers, as well as from a limited area.

The basic statistical data of the tested waters indicate that the highest concentrations of boron are found in $\mathrm{Cl}_{-}-\mathrm{HCO}_{3}-\mathrm{Na}$ and $\mathrm{HCO}_{3}-\mathrm{Cl}-\mathrm{Na}$ waters (Table 3, Figure 4).

Table 3. Descriptive statistics of the curative water dataset.

\begin{tabular}{ccccccccc}
\hline Type of Water & N & Mean & Median & Min. & Max. & $\begin{array}{c}\text { Standard } \\
\text { Deviation }\end{array}$ & $\begin{array}{c}\text { Coefficient } \\
\text { of Variation }\end{array}$ & $\begin{array}{c}\text { B = f(TDS) } \\
\text { PCC * }\end{array}$ \\
\hline Cl-HCO3-Na & 16 & 32.81 & 32.96 & 8.73 & 63.05 & 14.05 & 42.83 & 0.67 \\
HCO3-Cl-Na & 47 & 35.93 & 22.20 & 0.07 & 187.65 & 41.12 & 114.45 \\
Cl-Na & 50 & 23.94 & 7.01 & 1.00 & 135.17 & 35.94 & 150.11 \\
SO4 & 17 & 1.12 & 0.50 & 0.15 & 4.28 & 1.35 & 120.60 \\
HCO3-Ca (Na-Mg) & 118 & 1.05 & 0.47 & 0.05 & 14.00 & 2.04 & 193.64 \\
\hline
\end{tabular}

* PCC-Pearson correlation coefficient. 


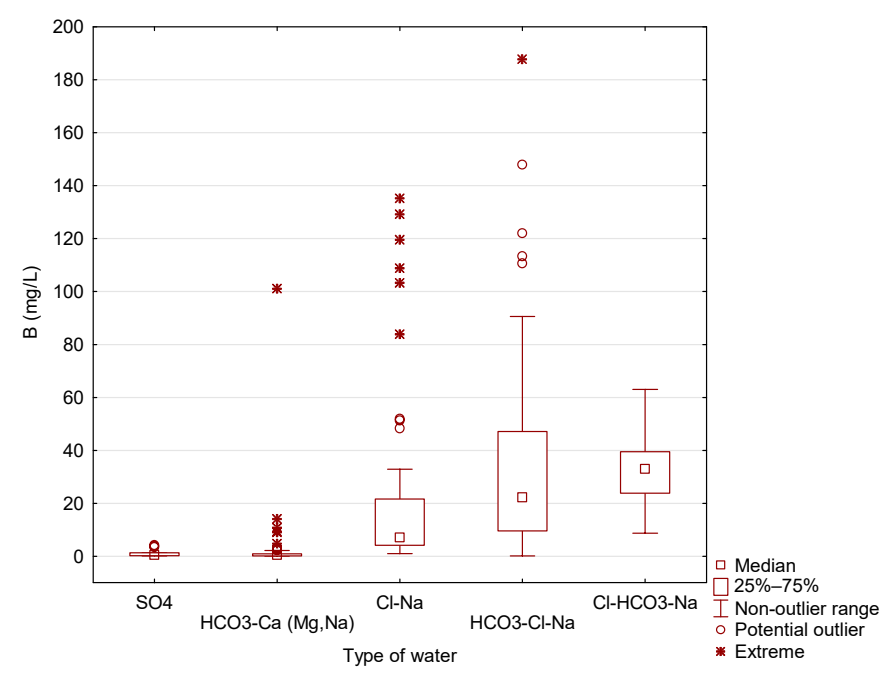

Figure 4. Boxplot of boron concentration in curative water in Poland.

Correlation analyses were performed for the concentrations of TDS and major ions $\left(\mathrm{Na}^{+}, \mathrm{Ca}^{2+}, \mathrm{Mg}^{2+}, \mathrm{Cl}^{-}, \mathrm{SO}_{4}{ }^{2-}, \mathrm{CO}_{3}{ }^{2-}\right.$ and $\left.\mathrm{HCO}_{3}{ }^{-}\right)$in relation to boron concentration, covering two aspects simultaneously, i.e., analysis of the graphical point distributions, and calculation the linear correlation coefficients. Boron concentration versus the sum of dissolved solids (mineralization of water) is shown in Figure 5. This relationship is presented both on a linear and logarithmic scale. The linear correlation coefficient for $\mathrm{Cl}-\mathrm{HCO}_{3}-\mathrm{Na}$ type waters is 0.67 (less than 0.7 ), and the graphical distribution of points may indicate the linear relationship between boron content and mineralization (Figure 5). However, the dataset contains a small amount of data $(\mathrm{N}=16)$ and it is difficult to draw general conclusions. In the case of waters of the $\mathrm{HCO}_{3}-\mathrm{Cl}-\mathrm{Na}$ type, almost a full correlation between boron concentration and mineralization of water is observed (Table 3, Figure 5). This correlation $(\mathrm{r}>0.7)$ is not seen in the case of other types of water.

In $\mathrm{HCO}_{3}-\mathrm{Cl}-\mathrm{Na}$ type waters, there is also a linear correlation between the boron concentration and the concentration of $\mathrm{HCO}_{3}{ }^{-}$and $\mathrm{Na}^{+}$ions, and the linear correlation coefficients are 0.95 and 0.91 , respectively (Figure 5). The value of the Pearson's correlation coefficient in the case of other correlations was below $0.7(\mathrm{r}<0.7)$.

The chemical composition of the analyzed water is presented in Figure 6 (Piper diagram). Boron in concentrations above $25 \mathrm{mg} / \mathrm{L}$ occurs only in sodium chloride and sodium bicarbonate waters. In this type of water, boron is present in various concentrations. Nevertheless, most waters of this type are characterized by concentrations above $5 \mathrm{mg} / \mathrm{L}$. It should also be noted that in waters with a high boron concentration, sodium dominates among the cations (present in an amount above $80 \%$ milivals-left triangle in the diagram), while among the anions, chlorides occur in various concentrations (from over $20 \%$ milivals to over $99 \%$-right triangle of the diagram). Boron in concentrations above $5 \mathrm{mg} / \mathrm{L}$ is not present in waters of magnesium chloride and calcium bicarbonate types. 


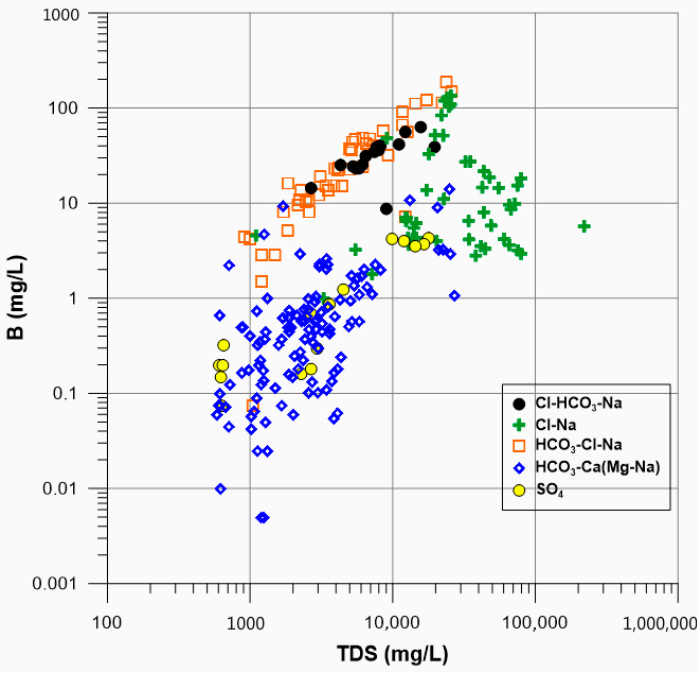

(a)

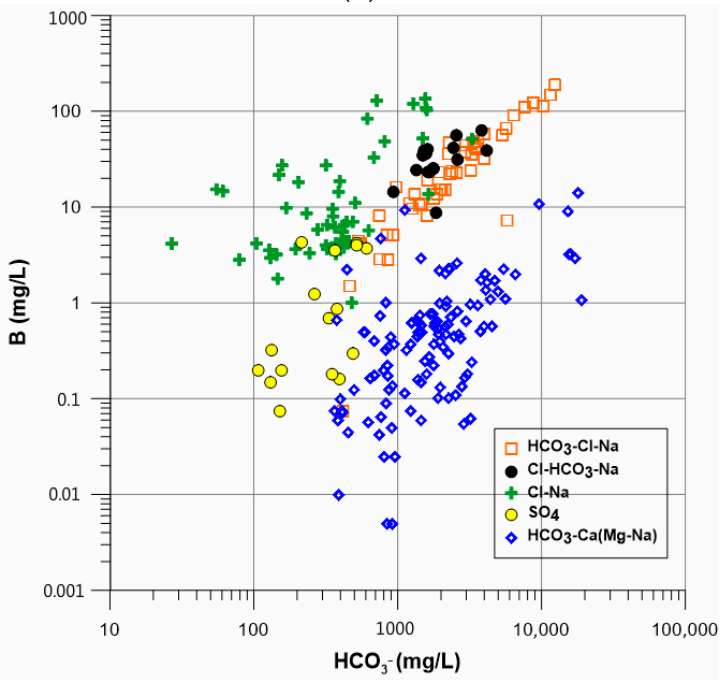

(c)

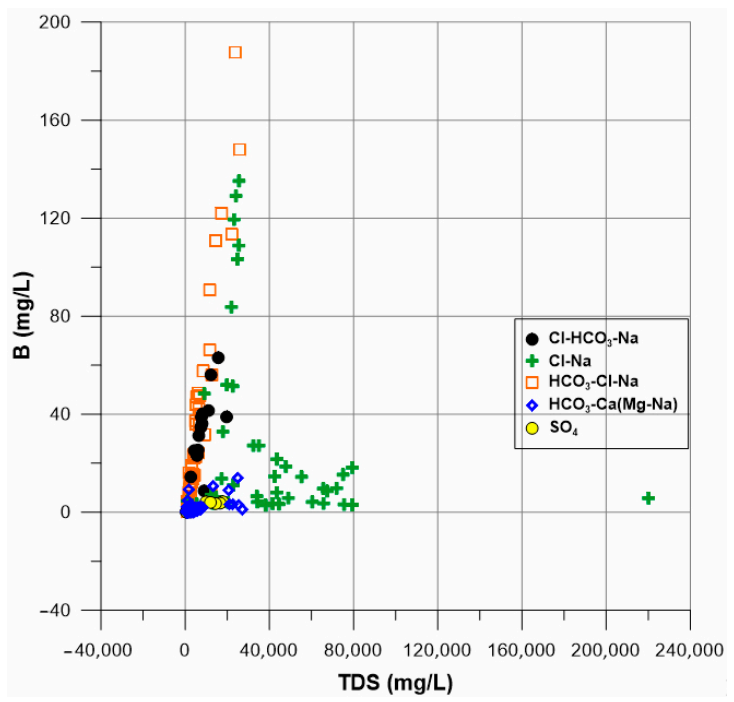

(b)

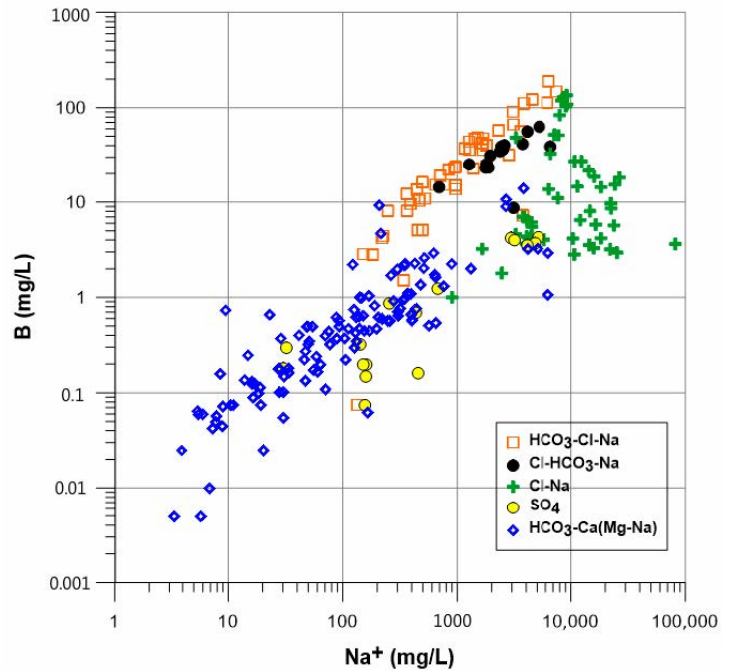

(d)

Figure 5. Boron concentration versus: (a) the sum of dissolved solids (mineralization of water)—double-logarithmic graph; (b) the sum of dissolved solids (mineralization of water) - linear graph; (c) $\mathrm{HCO}_{3}{ }^{-}$concentration-double-logarithmic graph (d) $\mathrm{Na}^{+}$concentration in curative waters-double-logarithmic graph. 


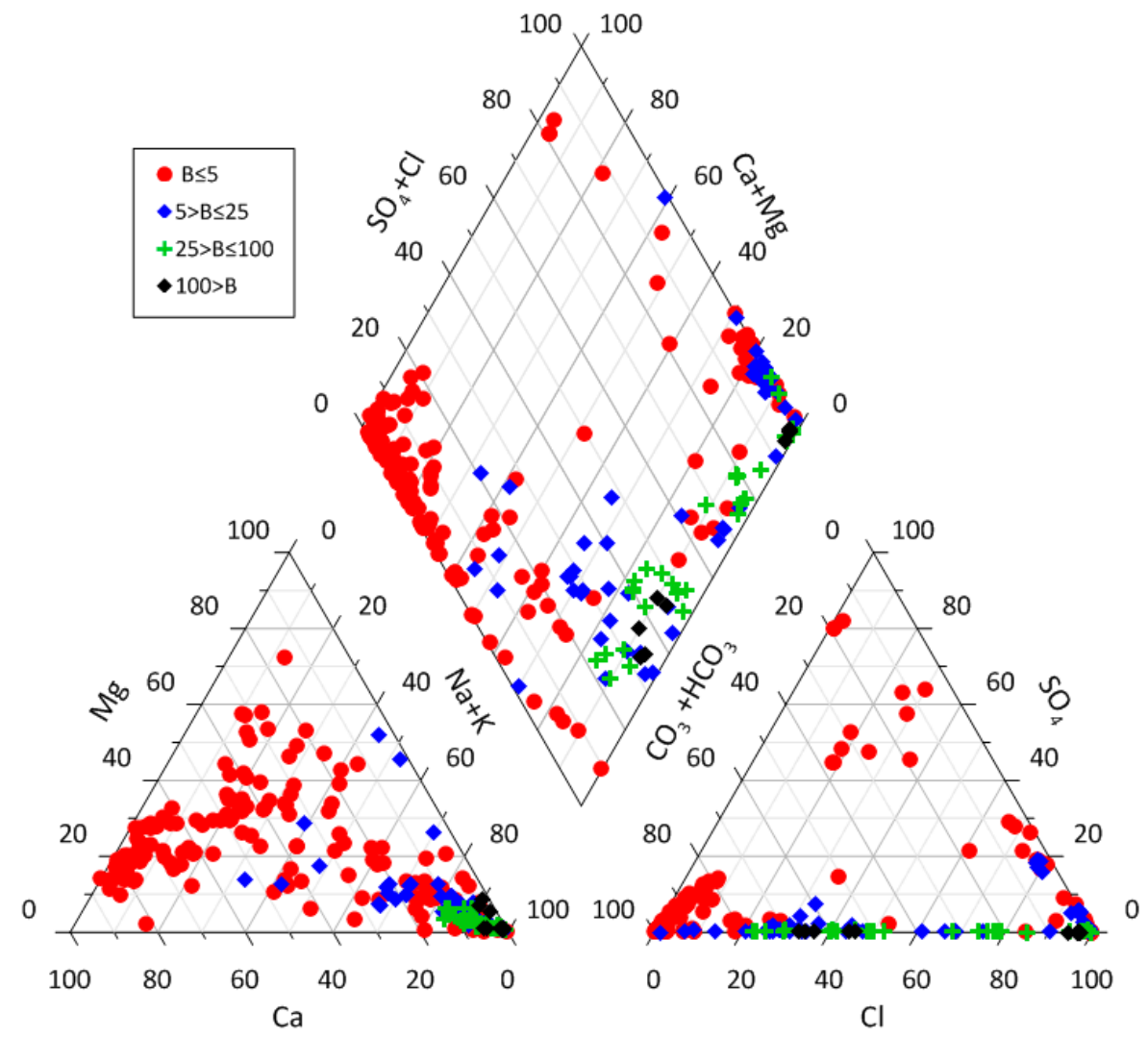

Figure 6. Piper diagram of curative water.

\section{Discussion}

\subsection{Boron and the Chemical Composition of Water}

The analyses conducted in this paper show a strong correlation between boron concentration and $\mathrm{Na}^{+}, \mathrm{HCO}_{3}{ }^{-}$ions and the sum of dissolved solids (mineralization of water) in the $\mathrm{HCO}_{3}-\mathrm{Cl}-\mathrm{Na}$ water type. The relationship between boron concentration and mineralization indicates that the origin of boron is determined by the same processes that influence the increase in mineralization. The factor determining the differentiation of the concentrations of individual ions is the time of water circulation. A large part of the water in which $\mathrm{HCO}_{3}{ }^{-}$ions are present in concentrations above $20 \%$ milivals comes from shallower depths (it either flows out from springs or is accessed through wells, which are exceptionally deep-up to $500 \mathrm{~m}$ ). In highly mineralized waters coming from deep circulation zones (usually Cl-Na type), the processes determining their chemistry are more complex. The lack of relationship between boron and other components may be the reason for this. In the literature, an evaluation of the processes controlling the geochemical constituents with the relationship of boron and other ions in waters has been conducted [78-80]. In these studies, the concentration of boron in waters was analyzed in the context of other chemical parameters (ion ratios). In the Polish waters analyzed by us, the $\mathrm{Cl} / \mathrm{B}$ molar ratio ranges from less than 1 to 11,090. The analyzed waters come from geologically diverse areas of Poland, and the obtained values of the $\mathrm{Cl} / \mathrm{B}$ molar ratio have a very wide range. Therefore, at the present stage of research, it is difficult to link the values of the $\mathrm{Cl} / \mathrm{B}$ molar ratio with the processes determining the chemistry of these waters.

The strong correlation between boron concentration and mineralization of water is not seen in investigated water types other than $\mathrm{HCO}_{3}-\mathrm{Cl}-\mathrm{Na}$. This is partly consistent with literature data from other regions of the world. The boron concentrations in selected Polish natural mineral and spring waters did not show any relationship between this component and mineralization [50]. Research on the chemistry of groundwater with different levels of mineralization from several regions of the world generally does not indicate a relationship 
between boron concentration and mineralization [81-83]. Nevertheless, an increase in boron concentration with mineralization is observed in the case of waters accompanying salt deposits. An example would be the waters of the Gorleben salt dome [84] or salt salars [85].

\subsection{The Influence of Boron on the Human Body and Legal Acts Regarding the Content of Boron in Water}

Boron is found in small amounts in the human body and is an important element for its proper functioning. The best sources of boron (1.0-4.5 mg/100 g) are dried fruits, nuts, avocados and legumes $[3,86]$. Boron is supplied to the human body by food, respiration and through the skin (especially damaged skin). The role of boron has not yet been fully defined. Beneficial effects of boron on calcium-phosphorus metabolism, i.e., the human skeletal system, have been found. Boron supports the absorption of calcium and its retention in the body, thereby preventing bone demineralization and osteoporosis $[87,88]$. Other benefits of boron supplementation are improvement of brain function and psychomotor response, and the treatment or prevention of arthritis [87-89].

The fact is that an excessive dose of boron is dangerous to humans. Numerous cases of poisoning with this component have been recorded. The tolerable upper intake levels (UL) of boron are 3, 6, 11 and $17 \mathrm{mg}$ /day for children ages 1-3, 4-8, 9-13 and 14-18 years, respectively. For adults, the UL is $20 \mathrm{mg}$ /day [90]. The upper level of boron intake is the highest daily intake of this nutrient that presents no risk of adversely affecting human health in the general population. The acute lethal dose of boron for humans is in the range of $0.4-0.9 \mathrm{~g} / \mathrm{kg}$ body weight [90].

The first WHO (World Health Organization) publication concerning water quality parameters was published in 1958 as 'International standards for drinking-water' [91]. In 1963 [92] and 1971 [93], the second and third editions of this book were published under the same title. Neither 'International standards for drinking-water' [91-93] nor 'European standards for drinking-water' [94,95] contained information about the content of boron in water. It was not until 1984 that boron was first mentioned in 'Guidelines for drinkingwater quality' (1st ed.) [96] and was listed among 37 inorganic constituents of potential health significance. At that time, however, a guideline value of boron was not suggested for drinking water. The second edition of 'Guidelines for drinking-water quality' in 1993 recommended that a safe concentration of boron was $0.3 \mathrm{mg} / \mathrm{L}$ [97]; in 1998 (in Addendum to Volume 1 on selected chemical substances), this was changed to $0.5 \mathrm{mg} / \mathrm{L}$ [98]. Recently, boron standards for safe drinking water have been relaxed, and the WHO has suggested changing the former adopted limit to $2.4 \mathrm{mg} / \mathrm{L}$ [99,100].

The European Union continues to recommend $1.0 \mathrm{mg} / \mathrm{L}$ as a safe concentration of boron in water intended for human consumption $[47,101]$. Despite changes in WHO guidelines, EU recommendations have retained the original more stringent boron concentration limits [47]. Polish law is in line with EU standards and the guide value for boron in water intended for human consumption is $1.0 \mathrm{mg} / \mathrm{L}[48,102]$. For natural mineral waters, the limit of boron concentration is $5.0 \mathrm{mg} / \mathrm{L}$ [103]. For medicinal water products, limits of 5.0 and $30.0 \mathrm{~g} / \mathrm{L}$ were set for drinking and inhalation lasting more than 1 month, respectively. No limits have been set for medicinal baths [104].

The presence of boron in the therapeutic waters of Poland has already been the subject of research [49-51,105,106]. The authors of previous studies indicated that $\mathrm{HBO}_{2}$ in a concentration above $5 \mathrm{mg} / \mathrm{L}$ (above $1.25 \mathrm{mg} / \mathrm{L}$ of boron) is present in 57 intake waters located in 16 health resorts. The larger set of data collected in our study confirms its frequent presence in medicinal waters.

In a large number of curative waters, the boron concentration is low (in 140 cases, it did not exceed $1 \mathrm{mg} / \mathrm{L})$. In the case of 46 waters $\left(15 \mathrm{Cl}-\mathrm{HCO}_{3}-\mathrm{Na}\right.$ type, $19 \mathrm{HCO}_{3}-\mathrm{Cl}-\mathrm{Na}$ type and $12 \mathrm{Cl}-\mathrm{Na}$ type), the boron concentration exceeded $25 \mathrm{mg} / \mathrm{L}\left(125 \mathrm{mg} / \mathrm{L}\right.$ of $\left.\mathrm{HBO}_{2}\right)$. These waters were found in nine locations (eight in the Carpathians and one on the Baltic coast-Kamien Pomorski). In the Carpathians, waters with boron concentration above 
$25 \mathrm{mg} / \mathrm{L}$ were found in five health resorts (Iwonicz, Rabka, Rymanów, Szczawnica and Wysowa), and the remaining three were found in Krościenko, Szczawa and Dębowiec.

However, the problem of high boron concentration in medicinal water is not without significance. In the case of 94 waters, the maximum permissible concentration value for water cure therapy ( $5 \mathrm{mg} / \mathrm{L}$ of $\mathrm{B}$ ) was exceeded. In 38 waters, the maximum permissible boron concentration for inhalation therapy was exceeded $(30 \mathrm{mg} / \mathrm{L}$ of $\mathrm{B})$. Curative waters are, in most cases, administered in pump rooms and are therefore are not widely available. However, it is important for consumers of these waters (including patients) to be aware that waters with a boron content above $5 \mathrm{mg} / \mathrm{L}$ should not be consumed for more than a month, and waters containing more than $25 \mathrm{mg} / \mathrm{L}$ boron should be consumed very carefully [49].

\subsection{The Prospect of Boron Recovery from Water with High Boron Content}

There is no doubt that modern economies will have to develop effective methods for removing boron from waters (sewage) in the near future due to the demand for this raw material and health and environmental issues. High concentrations of boron compounds in drinking water can be harmful for humans. Due to the standards regarding the maximum permissible boron content in drinking water, it is necessary to remove excess boron during water treatment. This would have a positive impact on the environment and create a new source of boron, which is especially valuable as the demand for this raw material is constantly growing.

An important aspect of effective boron recovery from water is the economic viability of the process. The boron concentration in an aqueous solution for which boron production would certainly be profitable depends on many factors (total water composition, market price of boron minerals, prices of materials and chemicals needed to run the process, etc.) Although simple, economical methods of boron production from water (sewage) on an industrial scale have not yet been developed, there is great interest in this topic, and we are convinced that these methods will soon be widely used. According to the Duyvestern et al. [16], a valuable concentration of boron in brine is 100 ppm, and in Russia boron content above $200 \mathrm{mg} / \mathrm{L}$ is considered to be industrially valuable [107].

Unfortunately, most water intakes with a high concentration of boron (above $100 \mathrm{mg} / \mathrm{L}$ ) are low-yielding wells [54,108-110] (Table S2). For example, in the Wysowa-Zdrój health resort, the designated exploitation resources range from $0.016 \mathrm{~m}^{3} /$ day (water intakeAleksandra) to $24 \mathrm{~m}^{3} /$ day (W-14 water intake) [54]. Therefore, it is unlikely that costeffective boron recovery, even on a small scale, could be achieved from a single water intake (potential production of $\mathrm{H}_{3} \mathrm{BO}_{3}$ in $\mathrm{kg}$ /day from this water is listed in Table S2). The analysis of the obtained data shows that the best candidate is the IG-II geothermal water intake in Rabka, with exploitation resources of $108 \mathrm{~m}^{3} /$ day [108] and potential production of ca. $80 \mathrm{~kg}$ of boric acid per day. However, in our opinion, simultaneous extraction of boron from several intakes in one place would bring the best expected economic effects. The analysis of the collected data shows that the best location for small-scale boron extraction would be Rabka, where five medicinal waters have boron content above $100 \mathrm{mg} / \mathrm{L}$ and their exploitation resources would add up.

\section{Conclusions}

The main aim of our work was to point out the problem of high content of boron in medicinal waters. For this purpose, the boron concentration in 248 water samples waters with medicinal certification was analyzed. The collected data set allowed for an examination of chemistry of these waters and also the possible relationships between boron concentration and other parameters of the curative waters. The tested waters were two-, three- and multi-ionic. According to the Szczukariew-Prikłoński classification, they belonged to a variety of groups: $\mathrm{Cl}-\mathrm{Na}, \mathrm{Cl}-\mathrm{HCO}_{3}-\mathrm{Na}, \mathrm{HCO}_{3}-\mathrm{Cl}-\mathrm{Na}, \mathrm{Cl}-\mathrm{SO}_{4}-\mathrm{Na}, \mathrm{SO}_{4}-\mathrm{Cl}-\mathrm{Ca}-$ $\mathrm{Na}, \mathrm{SO}_{4}-\mathrm{Cl}-\mathrm{HCO}_{3}-\mathrm{Mg}, \mathrm{SO}_{4}-\mathrm{HCO}_{3}-\mathrm{Na}, \mathrm{SO}_{4}-\mathrm{HCO}_{3}-\mathrm{Ca}-\mathrm{Mg}, \mathrm{SO}_{4}-\mathrm{HCO}_{3}-\mathrm{Cl}-\mathrm{Na}, \mathrm{SO}_{4}-\mathrm{Ca}$, $\mathrm{SO}_{4}-\mathrm{Ca}-\mathrm{Mg}, \mathrm{HCO}_{3}-\mathrm{Ca}-\mathrm{Mg}$ and $\mathrm{HCO}_{3}-\mathrm{Mg}-\mathrm{Na}$. It is interesting that in the case of the $\mathrm{HCO}_{3}$ $\mathrm{Cl}-\mathrm{Na}$ water type, a very good correlation (Pearson correlation coefficient of 0.93 ) between 
boron concentration and the sum of dissolved solids (mineralization of water) was found. This strong correlation was not seen in other types of investigated water, which is consistent with literature data from other regions of the world. Moreover, in the $\mathrm{HCO}_{3}-\mathrm{Cl}-\mathrm{Na}$ water type, $\mathrm{Na}^{+}$and $\mathrm{HCO}_{3}{ }^{-}$ions were also correlated with the boron content $(\mathrm{r}>0.7)$.

The collected data indicate that boron is a relatively common component of the investigated waters. In a large number of water samples, its content was rather low, and in 140 cases it did not exceed $1 \mathrm{mg} / \mathrm{L}$. However, the problem of high boron concentration in medicinal water is not without significance. In the case of 42 waters $\left(15 \mathrm{Cl}-\mathrm{HCO}_{3}-\mathrm{Na}\right.$ type, $19 \mathrm{HCO}_{3}-\mathrm{Cl}-\mathrm{Na}$ type and $12 \mathrm{Cl}-\mathrm{Na}$ type) from nine locations (Dębowiec, Iwonicz, Kamień Pomorski, Krościenko, Rabka, Rymanów, Szczawnica, Szczawa, Wysowa), the boron concentration exceeded $25 \mathrm{mg} / \mathrm{L}$, and 10 intakes of curative water had a boron concentration above $100 \mathrm{mg} / \mathrm{L}$. The highest boron content of $187.6 \mathrm{mg} / \mathrm{L}$ occurred in the Aleksandra intake at the Wysowa-Zdrój health resort. The current information regarding the narrow margin between deficiency and toxicity of boron in the human body may result in future in the loss of the medicinal certification for some waters. Of course, it should be remembered that the pharmacodynamic effect of boric acid alone in solution may differ from that of mineral water, in which boron is just one of many components.

The data we collected on boron concentration in therapeutic waters will also be useful when considering the prospects of boron recovery from these waters, especially since boron minerals are a sought-after raw material. Based on the collected data, taking into account not only the boron content, but also the value of water resources that can be exploited, the most promising would be the simultaneous production of boron from several water intakes in Rabka. The analysis of the obtained data shows that the best candidate is in Rabka the IG-II geothermal water, with exploitation resources of $108 \mathrm{~m}^{3} /$ day and potential production of ca. $80 \mathrm{~kg}$ of boric acid per day.

The increasing consumption of boron minerals works in two ways: on the one hand, we are looking for sources of borates; on the other hand, high consumption causes water and soil contamination with boron compounds. In both cases, there is a need to recover boron from aqueous solutions. Although simple, economical methods of boron production from water (sewage) on an industrial scale have not yet been developed; however, there is great interest in this topic, and we are convinced that these methods will soon be widely used.

Supplementary Materials: The following are available online at https:/ /www.mdpi.com/2075-163 X/11/1/8/s1, Table S1: Curative water and potentially curative water with concentration of boron above determination limit. Table S2. Characteristic of water intakes with a boron concentration above $100 \mathrm{mg} / \mathrm{L}$.

Author Contributions: Conceptualization, K.C.-L. methodology, B.W., K.C.-L.; software, K.C.-L., B.W., G.A.M., J.M., Ł.E.; validation, K.C.-L., B.W.; formal analysis, K.C.-L., B.W.; investigation, K.C.L., B.W.; resources, K.C.-L., B.W.; data curation, K.C.-L., B.W.; writing—original draft preparation, K.C.-L., B.W.; G.A.M. writing—review and editing, K.C.-L., B.W., G.A.M., J.M., Ł.Ł.; visualization, B.W., G.A.M.; supervision, K.C.-L.; project administration, K.C.-L.; funding acquisition, K.C.-L., B.W., J.M., Ł.Ł. All authors have read and agreed to the published version of the manuscript.

Funding: The paper was written within statutory research at the Faculty of Drilling, Oil and Gas at AGH University of Science and Technology in Krakow, Poland. No. 16.16.190.779.

Acknowledgments: The authors would like to thank Aleksandra Lewkiewicz-Małysa for her valuable help in collecting of unpublished physico-chemical analyzes of curative waters.

Conflicts of Interest: The authors declare no conflict of interest.

\section{References}

1. Brdar-Jokanović, M. Boron Toxicity and Deficiency in Agricultural Plants. Int. J. Mol. Sci. 2020, 21, 1424. [CrossRef] [PubMed]

2. Kot, F.S. Boron in the Environment. In Boron Separation Processes, 1st ed.; Kabay, N., Bryjak, M., Hilal, N., Eds.; Chapter 1; Elsevier: Amsterdam, The Netherlands, 2015; pp. 1-33.

3. Parks, J.L.; Edwards, M. Boron in the Environment. Crit. Rev. Environ. Sci. Technol. 2005, 32, 81-114. [CrossRef] 
4. Lewicka, E. Boron. In Minerals Yearbook of Poland 2013; Polish Geological Institute National Research Institute: Warszawa, Poland, 2015; pp. 143-152.

5. Helvaci, C. Geological features of neogene basins hosting borate deposits: An overview of deposits and future forecast, Turkey. Bull. Miner. Res. Explor. 2015, 151, 169-215. [CrossRef]

6. Zhang, X.; Li, G.; You, J.; Wang, J.; Luo, J.; Duan, J.; Zhang, T.; Peng, Z.; Rao, M.; Jiang, T. Extraction of Boron from Ludwigite Ore: Mechanism of Soda-Ash Roasting of Lizardite and Szaibelyite. Minerals 2019, 9, 533. [CrossRef]

7. Yu, J.; Hong, R.; Gao, C.; Cheng, A.; Zhang, L. Pinnoite Deposit in DaQaidam Saline Lake, Qaidam Basin, China: Hydroclimatic, Sedimentologic, and Geochemical Constraints. Minerals 2018, 8, 258. [CrossRef]

8. Weast, R.C. (Ed.) CRC Handbook of Chemistry and Physics; CRC Press Inc.: Boca Raton, FL, USA, 1988.

9. Butterwick, L.; Oude, N.; Raymond, K. Safety Assessment of Boron in Aquatic and Terrestrial Environments. Ecotoxicol. Environ. Saf. 1989, 17, 339-371. [CrossRef]

10. World Health Organization. Boron in Drinking-Water Background Document for Development of WHO Guidelines for Drinking-Water Quality; WHO Press: Geneva, Switzerland, 2009; Available online: https://www.who.int/water_sanitation_health/waterquality/guidelines/chemicals/boron-background.pdf (accessed on 20 October 2020).

11. Muhr, H.; Plasari, E.; Ouerdiane, I. Removal of Boron from Wastewater by Precipitation of a Sparingly Soluble Salt Patricia Remy. Environ. Prog. 2005, 24, 105-110.

12. Fan, X.; Yu, X.; Guo, Y.; Deng, T. Recovery of Boron from Underground Brine by Continuous Centrifugal Extraction with 2-Ethyl-1,3-hexanediol (EHD) and Its Mechanism. J. Chem. 2018; 1-8.

13. Zhang, R.; Xie, Y.; Song, J.; Xing, L.; Kong, D.; Li, X.-M.; He, T. Extraction of boron from salt lake brine using 2-ethylhexanol. Hydrometallurgy 2016, 160, 129-136. [CrossRef]

14. Tomaszewska, B.; Bodzek, M. Desalination of geothermal waters using a hybrid UF-RO process. Part I: Boron removal in pilot-scale tests. Desalination 2013, 319, 99-106. [CrossRef]

15. Kotowski, T.; Satora, S. Conception of the desalination plant at Bańska Niżna-usability of a post-process concentrate. Biul. Państwowego Inst. Geol. 2011, 445, 309-316. (In Polish)

16. Duyvesteyn, W.P.C.; Lastra, M.R.; Liu, H. Boron Recovery from Geothermal Brines. U.S. Patent US5236491, 17 August 1993.

17. Wilf, M.; Bartels, C.R.; Hirose, M. Methods for Reducing Boron Concentration in High Salinity Liquid. U.S. Patent US7442309B2, 28 October 2008.

18. Tao, F.T.; Pilger, P.F.; Dyke, C.A. Reducing Aqueous Boron Concentrations with Reverse Osmosis Membranes Operating at a High pH. U.S. Patent US5250185A, 5 October 1993.

19. Wilkomirsky, I. Process for Removing Boron from Brines. U.S. Patent US5939038A, 17 August 1999.

20. Da Silva, G.R.; Guilherme, T.M. Methods for Producing Lithium Carbonate and Sodium Borate from Calcium-Rich and Magnesium-Rich Brine. Patent WO2015035488A1, 19 March 2016.

21. Ezechi, E.H.; Isa, M.H.; Kutty, S.R.; Sapari, N.B. Boron recovery, application and economic significance: A review. In Proceedings of the 2011 National Postgraduate Conference, Kuala Lumpur, Malaysia, 19-20 September 2011; pp. 1-6.

22. Tagliabue, M.; Reverberi, A.P.; Bagatin, R. Boron removal from water: Needs, challenges and perspectives. J. Clean. Prod. 2014, 77, 56-64. [CrossRef]

23. Lin, J.-Y.; Shih, Y.-J.; Chen, P.-Y.; Huang, Y.-H. Precipitation recovery of boron from aqueous solution by chemical oxo-precipitation at room temperature. Appl. Energy 2016, 164, 1052-1058. [CrossRef]

24. Dydo, P.; Turek, M. Milewski, A Removal of boric acid, monoborate and boron complexes with polyols by reverse osmosis membranes. Desalination 2014, 334, 39-45. [CrossRef]

25. Dean, J.A. Lange's Handbook of Chemistry; McGraw-Hill: New York, NY, USA, 1999.

26. Dickson, A.G. Thermodynamics of the dissociation of boric acid in synthetic seawater from 273.15 to 318.15 K. Deep. Sea Res. Part A. Oceanogr. Res. Pap. 1990, 37, 755-766. [CrossRef]

27. Roy, R.N.; Roy, L.N.; Lawson, M.; Vogel, K.M.; Moore, C.P.; Davis, W.; Millero, F.J. Thermodynamics of the dissociation of boric acid in seawater at $\mathrm{S}=35$ from 0 to $55^{\circ} \mathrm{C}$. Mar. Chem. 1993, 44, 243-248. [CrossRef]

28. Kochkodan, V.; Darvish, N.B.; Hilal, N. The Chemistry of Boron in Water. In Boron Separation Processes, 1st ed.; Kabay, N., Bryjak, M., Hilal, N., Eds.; Chapter 1; Elsevier: Amsterdam, The Netherlands, 2015; pp. 35-63.

29. Su, C.M.; Suarez, D.L. Coordination of Adsorbed Boron: A FTIR Spectroscopic Study. Environ. Sci. Technol. 1995, $29,302-311$. [CrossRef]

30. Available online: https://www.statista.com/statistics/449828/worldwide-distribution-of-boron-end-use-by-application (accessed on 20 October 2020).

31. Available online: Tista.com/statistics/449813/global-prediction-of-medium-term-boric-acid-prices / (accessed on 20 October 2020).

32. Communication from the Commission to The European Parliament, The Council, The European Economic and Social Committee and the Committee of The Regions on the Review of the List of Critical Raw Materials for the EU and the Implementation of the Raw Materials Initiative (Document 52014DC0297). Available online: https://eur-lex.europa.eu/legal-content/EN/TXT/?uri= CELEX:52014DC0297 (accessed on 20 November 2020).

33. Available online: https://www.statista.com/statistics/264982/world-boron-reserves-by-major-countries / (accessed on 20 October 2020). 
34. Available online: https://pubs.usgs.gov/periodicals/mcs2020/mcs2020-boron.pdf (accessed on 4 December 2020).

35. Available online: https://www.statista.com/statistics/264981/major-countries-in-boron-production (accessed on 4 December 2020).

36. Available online: https://s3-us-west-2.amazonaws.com/prd-wret/assets/palladium/production/mineral-pubs/boron/ boronmcs06.pdf (accessed on 4 December 2020).

37. Available online: https:/ / www.mapsofworld.com/minerals/world-boron-producers.html (accessed on 4 December 2020).

38. Mermer, C.; Şengül, H. Addressing potential resource scarcity for boron mineral: A system dynamics perspective. J. Clean. Prod. 2020, 270, 122192. [CrossRef]

39. Hayes, S.M.; McCullough, E.A. Critical minerals: A review of elemental trends in comprehensive criticality studies. Resour. Policy. 2018, 59, 192-199. [CrossRef]

40. Graedel, T.E.; Harper, E.M.; Nassar, N.T.; Nuss, P.; Reck, B.K. Criticality of metals and metalloids. Proc. Natl. Acad. Sci. USA 2015, 112, 4257-4262. [CrossRef]

41. Henckens, M.; Driessen, P.P.J.; Worrell, E. Towards a sustainable use of primary boron. Approach to a sustainable use of primary resources. Resour. Conserv. Recycl. 2015, 103, 9-18. [CrossRef]

42. Łozinski, A.A. Wykłady Balneologii Ogólnej; Lectures of Balneology; PZWL: Warszawa, Poland, 1953; p. 28. (In Polish)

43. Lendle, L. Kritische zur Arsentherapie. Z. Andew. Bader-Klimaheilkd 1959, 6, 60-66. (In Germany)

44. Latour, T. The Evaluation Criteria and Generic Classification of Healing Mineral Waters" and Natural Mineral Waters". History, Present Time and New Amendments Proposals. Acta Balneol. 2018, 4, $253-257$.

45. Polish Journal of Laws of 2020, Item 1064. (USTAWA z dnia 9 czerwca 2011 r. Prawo Geologiczne i Górnicze). Available online: http:/ /isap.sejm.gov.pl/isap.nsf/download.xsp/WDU20111630981/U/D20110981Lj.pdf (accessed on 21 December 2020).

46. Nielsen, F.H. Boron in human and animal nutrition. Plant Soil. 1997, 193, 199-208. [CrossRef]

47. Directive of the European Parliament and of the Council on the Quality of Water Intended for Human Consumption (Recast) 2017/0332 (COD). Available online: https: / / eur-lex.europa.eu/legal-content/EN/TXT/?uri=COM\%3A2017\%3A753\%3AFIN (accessed on 21 December 2020).

48. Polish Journal of Laws of 2017, Item 2294. (Rozporządzenie Ministra Zdrowia w Sprawie Jakości Wody Przeznaczonej do Spożycia Przez Ludzi z dnia 7 Grudnia 2017 r. Dz.U. 2017, 2294. Available online: http:/ /isap.sejm.gov.pl/isap.nsf/download. xsp/WDU20170002294/O/D20172294.pdf (accessed on 21 December 2020).

49. Drobnik, M.; Latour, T. Therapeutic waters occurring in Szczawnica-the possibilities of their use in treatment. Balneol. Pol. 2006, 1, 40-45. (In Polish)

50. Święcicka, D.; Garboś, S. Determination of boron content in natural mineral and spring water using ICP-OES method. Rocz. Panstw. Zakl. Hig. 2009, 60, 329-332. (In Polish)

51. Drobnik, M.; Latour, T.; Sziwa, D. The assessment of health exposure resulted from barium, boron and fluoride intake from therapeutic waters available for resident people in water abstraction points of health resorts. Rocz. Państwowego Zakładu Hig. 2010, 61, 4. (In Polish)

52. Pozżaryski, W. Division of the area of Poland into tectonic units. In Geology of Poland, IV, Tectonic, Part 1; Polish Lowlands: Warsaw, Poland, 1974; pp. 24-34. (In Polish)

53. Ciężkowski, W.; Chowaniec, J.; Górecki, W.; Krawiec, A.; Rajche, L.; Zuber, A. Mineral and thermal waters of Poland. Przegląd Geol. 2010, 58, 762-773.

54. Rajchel, L. Carbonated Waters and Waters Containing Carbon Dioxide of the Polish Carpathians; Wydawnictwa AGH: Kraków, Poland, 2012. (In Polish)

55. Lisik, R. Sulphide Waters in the Busko-Zdrój Region; Wydawnictwo XYZ: Słupsk, Poland, 2010. (In Polish)

56. CCHP-Certificate Confirming Healing Properties of Waters Dobrowoda G-1. Available online: http://wlokniarz.pl/opis-wodyleczniczej] (accessed on 3 November 2020).

57. Lisik, R.; Szczepański, A. Sulphide Curative Waters in a Part of the Carpathian Foredeep; Wyd. POSTERIS: Kielce, Poland, 2014.

58. Lewkiewicz-Małysa, A.; Roszczynialska, K. Physico-chemical analyzes of curative waters from Busko, Iwonicz, Mateczny (Kraków), Polańczyk, Rabe, Rabka, Rymanów, Szczawa, Szczawnica, Wysowa, AGH University of Science and Technology, Kraków, Poland, 1996-2018. Unpublished work.

59. CCHP- Certificate Confirming Healing Properties of Waters Ciechocinek 14. Available online: http:/ / www.sanatoriumchemik. $\mathrm{pl} /$ solanka.htmlv (accessed on 3 November 2020).

60. Paczyński, B.; Płochniewski, Z. Mineral and Curative Waters of Poland; Państwowy Instytut Geologiczny: Warszawa, Poland, 1996. (In Polish)

61. Jarocka, A. Physical and chemical analyzes of curative waters, table waters and therapetic mud. Probl. Uzdrow. 1976, 9, 31-429. (In Polish)

62. Szmytówna, M. Balneochemistry-Chemistry of Mineral Waters and Peloids in Poland; Państwowy Zakład Wydawnictw Lekarskich: Warszawa, Poland, 1970. (In Polish)

63. CCHP-Certificate Confirming Healing Properties of Waters: Marysieńka. Available online: https: / www.google.com/url?sa=

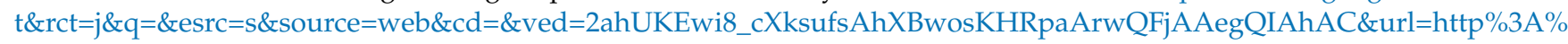
2F\%2Fbip.jeleniagora.pl\%2Fattachments\%2Fdownload\%2F17112\&usg=AOvVaw3WBbybH5cH7-w5Ask1jZtU (accessed on 3 November 2020). 
64. Dembska-Sięka, P. Therapeutic waters in Goczałkowice-Zdrój spa-its occurrence and usage. Przegląd Geol. 2015, 63, 672-677. (In Polish)

65. National Institute of Hygiene, Department of Health Resort Materials. CCHP-Certificate Confirming Healing Properties of WatersGotdap; National Institute of Hygiene, Department of Health Resort Materials: Warszawa, Poland, 2017. (In Polish)

66. Office of Designs and Technical Services of the Health Sector (Biuro Projektów I usług technicznych branży uzdrowiskowej). Spa Archives of Iwonicz-Zdrój; Office of Designs and Technical Services of the Health Sector: Warszawa, Poland, 1981. (In Polish)

67. Rasała, M.; Krawiec, A. Changes of chemical composition and genesis of the healing waters of Kamień Pomorski in the perspective of multi-year. Biul. Państwowego Inst. Geol. 2011, 445, 561-572. (In Polish)

68. Dowgiałło, J.; Kaczor, D.; Porowsk, I.A. Thermal Brines of the Polish Lowlands in the Light of Latest Investigations. Contemp Probl Hydrogeol 2007, 13, 52-63. (In Polish)

69. CCHP-Certificate Confirming Healing Properties of Waters Krynica Morska IG-1. Available online: http:/ / www.krynicamorska. tv/media/imgs/podstrony/file/pliki_do_pobrania/2016/swiadectwa/swiadectwo_wody.pdf (accessed on 3 November 2020).

70. Motyka, J.; Porwisz, B.; Rajchel, L.; Zuber, A. Mineral Waters of Krzeszowice. In Wspótczesne Problemy Hydrogeologii XI Sympozjum; University of Warsaw: Gdańsk, Poland, 2003; pp. 129-135. (In Polish)

71. Leszczyński, K. (Ed.) Grudziądz IG 1, Profiles of Deep Boreholes; 129; Polish Geological Institut: Warszawa, Poland, 2011; pp. 127-130. (In Polish)

72. Rajchel, L.; Czop, M. Hydrogeochemical mod el ling of chloride mineral water from Rabka spa (Carpathian Mountains, Poland). Geol. Quaterly 2012, 56, 681-690.

73. Dowgiałło, J.; Karski, A.; Potock, I. Geology of Balneological Resources; Wydawnictwa Geologiczne: Warszawa, Poland, 1969.

74. Zuber, A.; Weise, S.M.; Osenbrück, K.; Mateńko, T. Origin and age of saline waters in Busko Spa (Southern Poland) determined by isotope, noble gas and hydrochemical methods: Evidence of interglacial and pre-Quaternary warm climate recharges. Appl. Geochem. 1997, 12, 643-660. [CrossRef]

75. Płochniewski, Z. Mineral waters in Sopot. Przeglad Geol. 1974, 22, 315-318. (In Polish)

76. CCHP (Ustka)-Certificate Confirming Healing Properties of Waters. Available online: http://www.ustka.pl/pl/artykul/27/160 /operat-uzdrowiska-ustka (accessed on 2 November 2020).

77. Winid, B. Brine leaks related to the salt deposits and the importance of the analysis of their parameters in observation hydrogeological conditions on the example of Wieliczka Salt Mine. Ph.D. Thesis, AGH University of Science and Technology, Department of Drilling, Oil and Gas, Kraków, Poland, 2003. (In Polish).

78. Arnórsson, S.; Andrésdóttir, A. Processes controlling the distribution of B and $\mathrm{Cl}$ in natural waters in Iceland. Geochim. Cosmochim. Acta 1995, 59, 4125-4146. [CrossRef]

79. Halim, M.A.; Majumder, R.K.; Nessa, S.A.; Hiroshiro, Y.; Sasaki, K.; Saha, B.B.; Saepuloh, A.; Jinno, K. Evaluation of processes controlling the geochemical constituents in deep groundwater in Bangladesh: Spatial variability on arsenic and boron enrichment. J. Hazard Mater. 2010, 180, 50-62. [CrossRef]

80. Farmer, J.R.; Branson, O.; Uchikawa, J.; Penman, D.E.; Hönisch, B.; Zeebe, R.E. Boric acid and borate incorporation in inorganic calcite inferred from B/Ca, boron isotopes and surface kinetic modeling. Geochim. Cosmochim. Acta 2019, 244, 229-247. [CrossRef]

81. Kumar, M.B. Character of meteoric leaks in the salt mines of south Louisiana, USA. J. Hydrol. 1983, 66, 351-368. [CrossRef]

82. Bianchini, G.; Pennisi, M.; Cioni, R.; Muti, A.; Cerbai, N.; Kloppmann, W. Hydrochemistry of the high-boron groundwaters of the Cornia aquifer (Tuscany, Italy). Geothermics 2005, 34, 297-319. [CrossRef]

83. Gemici, Ü.; Tarcan, G.; Helvaci, C.; Somay, A.M. High arsenic and boron concentrations in groundwaters related to mining activity in the Bigadic borate deposits (Western Turkey). Appl. Geochem. 2008, 23, 2462-2476. [CrossRef]

84. Kloppmann, W.; Negrel, P.; Casanova, J.; Klinge, H.; Schelkes, K.; Guerrot, C. Halite dissolution derived brines in the vicinity of Permian salt dome (N German Basin). Evidence from borom, strontium, oxygen, and hydrogen isotopes. Geochim. Cosmochim. Acta. 2001, 65, 4087-4101. [CrossRef]

85. Risacher, F.; Fritz, B.; Alonso, H. Non-conservative behaviour of bromine in surface waters and brines of Central Andes: A release into the atmosphere? Geochim. Cosmochim. Acta 2006, 70, 2143-2152. [CrossRef]

86. Naghii, M.R.; Wall, P.M.; Samman, S. The boron content of selected foods and the estimation of its daily intake among free-living subjects. J. Am. Coll. Nutr. 1996, 15, 614-619. [CrossRef] [PubMed]

87. Miggiano, G.A.; Gagliardi, L. Diet, nutrition and bone health. Clinica Terapeutica 2005, 156, 47-56.

88. Nielsen, F. Biochemical and Physiologic Consequences of Boron Deprivation in Humans. Environ. Health Perspect. 1994, 102 (Suppl. S7), 59-63.

89. Newnham, R.E. The role of boron in human nutrition. J. Appl. Nutr. 1994, 46, 81-85.

90. Białek, M.; Czauderna, M.; Krajewska, K.A.; Przybylski, W. Selected physiological effects of boron compounds for animals and humans. A review. J. Anim. Feed. Sci. 2019, 28, 307-320. [CrossRef]

91. World Health Organization. International Standards for Drinking-Water, 1st ed.; 78; World Health Organization: Geneva, Switzerland, 1958.

92. World Health Organization. International Standards for Drinking-Water, 2nd ed.; World Health Organization: Geneva, Switzerland, 1963.

93. World Health Organization. International Standards for Drinking-Water, 3rd ed.; World Health Organization: Geneva, Switzerland, 1971. 
94. World Health Organization. European Standards for Drinking-Water, 1st ed.; World Health Organization: Geneva, Switzerland, 1961.

95. World Health Organization. European Standards for Drinking-Water, 2nd ed.; World Health Organization: Geneva, Switzerland, 1970.

96. World Health Organization. Guidelines for Drinking-Water Quality, 1st ed.; World Health Organization: Geneva, Switzerland, 1984.

97. World Health Organization. Guidelines for Drinking-Water Quality, 2nd ed.; World Health Organization: Geneva, Switzerland, 1993; Volume 1.

98. World Health Organization. Guidelines for Drinking-Water Quality, 2nd ed.; World Health Organization: Geneva, Switzerland, 1998; Volume 2.

99. World Health Organization. Guidelines for Drinking-Water Quality, 4th ed.; World Health Organization: Geneva, Switzerland, 2011.

100. World Health Organization. A Global Overview of National Regulations and Standards for Drinking-Water Quality; World Health Organization: Geneva, Switzerland, 2018.

101. Ljujic, B.; Sundac, L.J. EC Council Directive 98/83/EC of 3 November 1998 on the quality of water intended for human consumption. J. Eur. Communities 2005, 330, 32-54.

102. Polish Journal of Laws of 2010, Item 466, (Rozporządzenie Ministra Zdrowia z dnia 20 Kwietnia 2010 r. Zmieniajace Rozporzadzenie w Sprawie Jakości Wody Przeznaczonej do Spożycia Przez Ludzi. Dz. U. 2010. Available online: http://isap.sejm.gov.pl/isap. nsf/DocDetails.xsp?id=WDU20100720466 (accessed on 21 December 2020).

103. Polish Journal of Laws of 2011, item 85 (Rozporządzenie Ministra Zdrowia z dnia 31 Marca 2011 r. w Sprawie Naturalnych wód Mineralnych, wód Źródlanych i wód Stołowych. Dz. U. 2010). Available online: http:/ /isap.sejm.gov.pl/isap.nsf/DocDetails. xsp?id=WDU20110850466 (accessed on 21 December 2020).

104. Polish Journal of Laws of 2006, Item 80 (Rozporządzenie Ministra Zdrowia z dnia 13 Kwietnia 2006 r. w Sprawie Zakresu Badań Niezbędnych do Ustalenia Właściwości Leczniczych Naturalnych Surowców Leczniczych i Właściwości Leczniczych Klimatu, Kryteriów ich Oceny Oraz Wzoru Świadectwa Potwierdzającego te Właściwości Dz. U. 2010). Available online: http:/ /isap.sejm.gov.pl/isap.nsf/DocDetails.xsp?id=WDU20060800565 (accessed on 21 December 2020).

105. Drobnik, M.; Latour, T. Investigation of the pharmacodynamic properties of the solution of boric acid. Rocz. Panstw. Zakl. Hi 2001, 52, 33-39. (In Polish)

106. Drobnik, M.; Latour, T. Physiological importance of mineral components in natural mineral water according pharmacodynamic investigation of some therapeutic mineral waters. J. Elem. 2006, 11, 259-270. (In Polish)

107. Balderer, W.; Porowski, A.; Idris, H.; LaMoteaux, J.W. Thermal and Mineral Waters: Origin, Properties and Applications; Springer: Berlin/Heidelberg, Germany, 2014; p. 114.

108. Boratyn, J.; Lis, J.; Malata, T.; Pasieczna, A.; Patorski, R.; Radwanek-Bąk, B.; Romanek, A.; Tomassi-Morawiec, H. OBJAŚNIENIA DO MAPY GEOŚRODOWISKOWEJ POLSKI 1: 50,000-Arkusz RABKA (1032); Państwowy Instytut Geologiczny: Warszawa, Poland, 2004. Available online: http:/ / bazadata.pgi.gov.pl/data/mgsp/txt/mgsp1032.pdf (accessed on 21 December 2020).

109. Rajchel, L.; Józefko, I.; Motyka, J.; Rajchel, J. Reserves and utilization of mineral waters of Szczawa, Krościenko and Szczawa. In Wspótczesne Problemy Hydrogeologii; University of Warsaw: Gdańsk, Poland, 2003; pp. 43-50. (In Polish)

110. Porwisz, B. On the Trail of Curative and Thermal Waters in Małopolska. Wydawnictwo Kartograficzne "Compass" Kraków. 2013. Available online: https://www.google.com/url?sa=t\&rct=j\&q=\&esrc=s\&source=web\&cd=\&ved=2ahUKEwiixsOdn7 ftAhUKxYsKHWMMAW4QFjACegQIAxAC\&url=https\%3A\%2F\%2Fwww.malopolska.pl\%2Ffile\%2Fpublications\%2FSzlakiem_ wod_termalnych_i_leczniczych_w_Malopolsce_2013.pdf\&usg=AOvVaw0F7Q91YNxMg0qE2B35UAkU (accessed on 1 December 2020). (In Polish). 